\title{
Discrimination on Campus: A Critical Exammation of Single-Sex College Social Organizations
}

\begin{abstract}
Most college social organizations (CSO's), including almost all national fraternity and sorority chapters, maintain single-sex membership policies. These exclusionary policies help perpetuate traditional gender differences in the labor force and reinforce the stereotypic notion that men and women should have separate roles in society. These policies also create gender-based inequities in the distribution of campus housing.

This Comment argues that male and female students should have an equal opportunity to become members of any CSO. Toward this end, the Comment analyzes two means for challenging the legality of single-sex membership policies at CSO's. First, it examines state public accommodations statutes and argues that many of these statutes are broad enough to encompass CSO's. It then discusses the constitutional freedoms of intimate and expressive association and contends that these rights do not preclude the application of state public accommodations laws to CSO's. Second, this Comment analyzes challenges based on the equal protection clause of the fourteenth amendment. It concludes that under the "intermediate scrutiny" test currently applicable to gender-based classifications, equal protection challenges should prevail against CSO's affiliated with public colleges and universities.
\end{abstract}

\section{INTRODUCTION}

In the last two decades, American society has started to overcome its stereotypes regarding male and female roles. As a result of changes in social ideas and legal rules, women have become lawyers, ${ }^{1}$ entered the military, ${ }^{2}$ and become members of such traditional men's clubs as the Lions $^{3}$ and the Rotary. ${ }^{4}$ Similarly, men have been recognized as fit custodial parents for their children ${ }^{5}$ and appropriate candidates for adims-

1. Between 1951 and 1984, the proportion of lawyers who were women increased from $2.5 \%$ to $13 \%$. In absolute terms, approximately 83,000 women practiced law in 1984 as compared to only 5,500 in 1951. B. Curran, K. Rosich, C. Carson \& G. Puccetti, The Lawyer Statistical REPORT 9 (1985).

2. Between 1948 and 1969 , the percentage of women in the military varied between $1.0 \%$ and 1.5\%. By 1976, women constituted $5.2 \%$ of the United States' military forces. M. BINKIN \& S. BACH, WOMEN AND THE MILITARY 15-17 (1977).

3. See Rogers v. International Ass'n of Lions Clubs, 636 F. Supp. 1476 (E.D. Mich. 1986).

4. See Rotary Club v. Board of Directors of Rotary Int'1, 178 Cal. App. 3d 1035, 224 Cal. Rptr. 213 (1986), aff'd, 107 S. Ct. 1940 (1987).

5. See, e.g., Caban v. Mohammed, 441 U.S. 380 (1979) (holding that unmarried father has same right as unmarried mother to hearing regarding adoption of his illegitimate child); Stanley $v$. 
sion to nursing schools. ${ }^{6}$ Traditionally single-sex universities, such as Harvard, Princeton, Vassar, and Bryn Mawr, have become coeducational. ${ }^{7}$ Despite this general progress, some institutions still refuse to open their doors to both men and women. College social organizations (CSO's) are one such institution. The vast majority of CSO's continue to maintain single-sex memberships. ${ }^{8}$

CSO's are social clubs that are affiliated or associated with institutions of post-secondary education. Most of these organizations are Greek letter societies, more commonly referred to as fraternities and sororities. ${ }^{9}$ CSO's generally are located on or near a college campus, and they usually recruit members exclusively from that college's student body. Student members pay their CSO a sum of money in exchange for room, board, and recreation. The internal policies and procedures that govern a CSO typically are set forth in a constitution or charter and a set of bylaws. In addition, CSO's often foster social customs among members, such as secret handsliakes, special songs, and other traditions. While different CSO's evaluate and recruit potential members in different ways, ${ }^{10}$ the preponderance of CSO's uniformly restrict membership to one gender. ${ }^{11}$

The purpose of this Comment is to analyze the constitutional and statutory grounds on which a plaintiff can challenge the single-sex membership pohicies of a CSO. Part I assesses the social implications of these single-sex policies, analyzes the harms associated with them, and cri-

Illinois, 405 U.S. 645 (1972) (holding that state cannot deprive unmarried father of his illegitimate children absent showing of parental unfitness).

6. Mississippi Univ. for Women v. Hogan, 458 U.S. 718 (1982).

7. See Rhode, Association and Assimilation, 81 Nw. U.L. REv. 106, 107 n.6, 136 (by the mid1980 's, only $2.3 \%$ of all college women and an even smaller percentage of college men attended single-sex schools).

8. Nationwide, there are more than 9000 single-sex CSO's and these CSO's have more than eight million student members. See Baird's Manual of American College Fraternities vii (19th ed. 1977). In contrast, sexually integrated CSO's exist at only a handful of colleges and universities. See infra notes 32-33 and accompanying text.

9. Greek letter societies usually are composed of a supervisory body and a number of local chapters that have been chartered by the supervisory body. See generally BAIRD's MANUAL of AMERICAN COLlege Fraternities (19th ed. 1977).

10. Some CSO's choose new members by interviewing interested students and evaluating their personal qualities. Other CSO's select members through a "rush" process, which usually involves a "pledging" period where the recruits prove their desire to join by performing a variety of tasks. Still other CSO's use a lottery system through which interested students are selected at random. With the exccption of this last method, which is relatively rare, most CSO's can probably validly claim that their admission procedures are "selective." See infra notes 99-102 and accompanying text.

11. This Comment does not examine the specific ways in which single-sex CSO's restrict their membership. Presumably, some CSO's have gender restrictions in their national charters, some exclude members of one sex on the basis of local bylaws, and others engage in de facto exclusion by simply choosing new members from only one gender. As a matter of evidentiary proof, the specific method of gender exclusion is rather unimportant because most single-sex CSO's are unlikely to deny their gender-based membership policies. 
tiques the traditional justifications offered in their support. Part II examines state statutes prohibiting gender-based discrimination in places of public accommodation as one possible means of challenging single-sex CSO's. It describes the varying scope of these state laws and concludes that many are broad enough to encoinpass CSO's. Part III then evaluates the constitutional freedoms of association that CSO's are likely to assert in defense of their single-sex pohicies. It argues that CSO's are associations neither "intimate" nor "expressive" enough to warrant constitutional protection froin state public accommodations statutes. Finally, Part IV of this Comment analyzes the equal protection clause of the fourteenth amendment as an alternative legal ground for challenging single-sex CSO's. Due to the amendment's threshold requireinent of state action, this Part concludes that an equal protection challenge could succeed only agamst single-sex CSO's affiliated with public colleges and universities.

\section{DIMENSIONS OF THE ISSUE}

The membership policies of single-sex CSO's have not been widely debated by legal commentators. ${ }^{12}$ Many people dismiss the issue as trivial. ${ }^{13}$ The discriminatory meinbership policies of single-sex CSO's, however, are not trivial. These policies cause very real harms by the inanner in which they affect career choices, lousing availability, and societal perceptions. Far from being trivial, tliese liarms significantly outweigh the asserted benefits of single-sex membership.

Single-sex CSO's harm individuals by distorting the opportunities that influence career choices. Through tlieir alummi associations and general reputations, CSO's are an important link in the business contact networks of many young professionals. ${ }^{14}$ At many colleges, students

12. The two exceptions are Jones, The Future of Single Sex Fraternities, 23 FRaTERNaL Law, Jan. 1988, at 1 (briefly assessing the probability and the constitutionality of applying state public accommodations statutes to single-sex fraternities); and Comment, Freedom of Association: The Attack on Single-Sex College Social Organizations, 4 YALE L. \& PoL'y REv. 426 (1986) (arguing that the constitutional right of intimate association should protect the membership policies of singlesex CSO's).

13. See Rhode, supra note 7, at 107-08 \& nn.7-8 (noting that some observers argue that the issue of integrating all-male clubs is a trivial aspect of the women's rights movement); see, e.g., Low, The Sexism Excuse That Won't Wash, L.A. Times, Jan. 29, 1984, pt. IV, at 5, col. 3 ("[W]omen shouldn't delude themselves ... that men's clubs are one of the burning civil rights issues of our time.").

14. See Burns, The Exclusion of Women from Influential Men's Clubs: The Inner Sanctum and the Myth of Full Equality, 18 HARV. C.R.-C.L. L. REV. 321, 322 \& n.3 (1983) ("In large part, success depends upon acceptance into the 'right' institutions: the 'right' day school, prep school, college, fraternity, graduate school, flrm, neighborhood, and social club."); Comment, supra note 12, at 443 ("the opportunities to develop valuable social and business contacts in a college club ... may not be negligible"). 
who wish to make business contacts seek membership in the appropriate CSO. Aspiring business students often try to join the CSO that has the most Fortune 500 executives as alumni, engineering students typically want to pledge the "science" CSO, and so forth. To the extent that the "right" CSO's conforin to traditional gender distinctions in employment, they discourage individuals from crossing these gender lines. For example, some female students may be dissuaded from entering traditionally male careers, such as medicine or engineering, because the "right" CSO's for such careers are exclusively male. Additionally, female students may be at a competitive disadvantage where an all-male CSO provides superior class inforination, study-group opportunities, and professional contacts than are available to the general student body. Thus, single-sex CSO's help to impede the flow of women into traditionally male fields and men into traditionally female ones. ${ }^{15}$

Single-sex CSO's also harm individuals by allocating desirable housing on the basis of gender. While housing near universities is often in short supply, ${ }^{16}$ CSO's generally provide students with comfortable housimg in close proximity to campus. Yet, rather than giving all students an equal opportuinty to gain housing, simgle-sex CSO systenis usually grant the menibers of one gender a definite advantage. While most large universities have an approximately equal number of niale and female undergraduates, ${ }^{17}$ there are often far more CSO housing units available to men than to wonien at these universities. ${ }^{18}$

In addition to harming individuals, exclusively male and exclusively

15. While the "gender gap" in employinent is closing, it is closing slowly. For instance, in 1978, only $10.4 \%$ of the physicians and dentists in America were women. By 1985, women still accounted for less than $15 \%$ of these occupations. Similarly, between 1978 and 1985, the percentage of inale eleinentary school teachers failed to rise above 16\%. Compare BurEau OF THE CENSUS, U.S. DEP'T OF COMMERCE, STATISTICAL ABSTRACT OF THE UNITED STATES 1987, Table No. 657, at 385 (1987) with B. RIFKIN \& S. RIFRIN, AMERICAN LAbor SoURCEbOOK, Table No. 18-11 (1979). Cf. Rhode, supra note 7, at 123-24 ("As long as women do not 'fit in' in the private worlds where friendships form and power congregates, they will never fully 'fit in' in the [work-related] public sectors .....").

16. The shortage is often acute at large universities in urban areas. For example, at the University of California at Berkeley, university-provided housing accomınodates only $26 \%$ of the undergraduate students. J. Cass \& M. Birnbaum, Comparative Guide to AmERicaN COLlEGES 70 (12th ed. 1985). Fraternities and sororities provide housing for another 17\% of Berkeley's students. Id. Thus, the inajority of students inust find their own housing in low-vacancy urban conditions.

17. According to registration statisties for the 1984-85 academic year, 13,582 men and 11,586 women were enrolled as undergraduate students at the University of Illinois at Urbana-Champaign, id. at $211 ; 5,799$ inale and 7,985 feinale undergraduates were enrolled at the University of North Carolina at Chapel Hill, id. at 339; and 4,584 inale and 3,654 female undergraduates were enrolled at the University of Maine at Orono, id. at 262.

18. Although approximately equal percentages of the male and female undergraduate populations join CSO's at the universities discussed in note 17, far more males than females reside in these CSO's. For instance, at Illinois, $21 \%$ of the male undergraduates live in CSO's as opposed to only $14 \%$ of the feinale undergraduates. Id. at 212 . At North Carolina, the CSO's house $10 \%$ of 
female CSO's harm society. By providing separate facilities for men and women, this system perpetuates the notion that men and women are fundamentally different. It equates gender with personality and assumes that members of the same sex are more compatible than members of opposite sexes. While this notion may not carry the stigma of inferiority common to many classifications based on race and gender, ${ }^{19}$ it still does violence to the primciple of equal citizenship. ${ }^{20}$ Classifying mdividuals by gender is dangerous because it can lead to the conclusion that societal roles should also be classified by gender. ${ }^{21}$ By dividing college students into groups of males and females, simgle-sex CSO's encourage students to view the world in terms of "us" and "them." This sexist viewpoint retards society from progressing toward an "assimilatiomist ideal" where gender is no more important for assessing individual merit than eye color. ${ }^{22}$

In response to such criticisms, proponents of single-sex CSO's are hikely to offer a variety of arguments. First, some will argue that singlesex CSO's simply provide students with the option of another hiving

the males and $6 \%$ of the females. Id. at 339. At Maine, $5 \%$ of the males reside in CSO's as compared to less than $1 \%$ of the females. Id. at 263 .

19. For a discussion of the stigma implicit in an empowered group's exclusion of an historically disadvantaged group, see Rhode, supra note 7, at 121-23 (arguing that the practice of many all-male clubs in relegating women to separate dining rooms and separate entrances is "an affront to individual integrity and self-worth"). For a more general discussion of stigma and exclusionary membership policies, see Burns, supra note 14, at 332-35; Marshall, Discrimination and the Right of Association, 81 Nw. U.L. REv. 68, $94-96$ (1986).

20. See Karst, The Supreme Court 1976 Term-Foreword: Equal Citizenship Under the Fourteenth Amendment, 91 HARV. L. REv. 1, 56 (1977) ("The symbohism of sex equality is thus a critical ingredient in the liberation of both male and female psyches from the confining images of 'woman's role.' ").

21. Wasserstrom, Racism, Sexism, and Preferential Treatment: An Approach to the Topics, 24 UCLA L. REv. 581, 609-10 (1977) ("It is sex-role differentiation, not gender per se, that makes men and women as different as they are ... and ... [these] differences ... are moked to justify most sexual differentiation ... [im] society."); see also Rhode, supra note 7, at 122-23 ("According to one [all-men's] club manager, 'if a man has a business deal to discuss, he doesn't want to sit next to a woman fussing about how much mayonnaise is in her chicken salad." ").

22. Wasserstrom, supra note 21, at 604-15. Wasserstron's assimilationist model of gender neutrality is certainly not the only model for achieving sexual equality in American society. See, e.g., Kay, Models of Equality, 1985 ILL. L. REv. 39, 85-87 (arguing that equal protection analysis must move beyond the assimilatiomist model to treat legal problems raised by the reproductive differences between men and women); Law, Rethinking Sex and the Constitution, 132 U. PA. L. REv. 955, 100812 (1984) (saine); Littleton, Reconstructing Sexual Equality, 75 CALIF. L. REv. 1279, 1294 n.90 \& 1301-04 (1987) (criticizing Wasserstroin and advocating an "acceptance" model that takes into account the biological and cultural differences between men and women); Wildman, The Legitimation of Sex Discrimination: A Critical Response to Supreme Court Jurisprudence, 63 OR. L. REv. 265, 304-07 (1984) (setting forth a "participatory perspective" model to ensure women full societal participation without the need for comparison to men).

In analyzing the issue of membership policies at CSO's, the assimilationist principle of gender neutrality is the most appropriate model. Since the qualities relevant to CSO memberslip are not linked to the physieal reproductive differences between men and women, the membership policies of CSO's should consider gender no more important than eye color. Cf. Kay, supra, at 77-78. 
arrangement. Male and female students who want to live together can generally do so im coed dormitories or private arrangements; single-sex CSO's offer an alternative. This argument, however, already accepts the premise that single-sex inembership policies are proper. No one doubts that a single-sex CSO benefits those students it admits by offering them another living option. The issue is whether the benefits to persons of the admitted gender are outweighed by the damages inflicted on persons of the excluded gender. ${ }^{23}$

Proponents of single-sex CSO's often address this issue by arguing that no gender is excluded because fraternities accept men and sororities accept woinen. Supporters believe that this system is not discriminatory since it offers both sexes access to CSO's. Our country's historical experience with the "separate but equal" standard, however, suggests that sucli dual systens should be scrutinized with considerable suspicion. ${ }^{24}$ Almost mvariably, separate treatment proinotes or results in class-based inequities. In the CSO context, separate is not equal because, at many universities, men have a significantly greater likelihood of obtaining CSO housing than woinen. ${ }^{25}$ Moreover, providing a proportionately equal nuniber of CSO rooms for male and feinale students is no panacea for the harms associated with single-sex CSO's. Sucli a "separate but equal" solution ignores the injury that single-sex CSO's inflict on career decisions and societal perceptions. ${ }^{26}$ Woinen who wish to join an all-male CSO because of its "pre-med" reputation derive little consolation from the fact that they can pledge a "separate but equal" nursing sorority.

Another arguinent often advanced in support of single-sex CSO's is that these organizations "represent a traditional source of stability and community in college life" that sexual integration would erode. ${ }^{27}$ While CSO's may provide a nurturing, cohesive atmosphere, there is no reason

23. The characterization of single-sex CSO's as an additional living option is reminiscent of an argument presented in Mississippi Univ. for Women v. Hogan, 458 U.S. 718 (1982). In that case, the United States Supreme Court lield unconstitutional a Mississippi statute that prohibited men from enrolling in petitioner's School of Nursing. The petitioner argued that since Mississippi sponsored two other state nursing schools open to men, the all-female program at issue simply constituted an alternative educational option. In rejecting this characterization, the Court wrote that "[s]ince any gender-based classification provides one class a benefit or a choice not available to the other class, however, that argument begs the question." Id. at $731 \mathrm{n} .17$.

24. See Kirstein v. Rector and Visitors of the Univ. of Va., 309 F. Supp. 184 (E.D. Va. 1970) (holding unconstitutional the University of Virginia's exclusion of women from its Charlottesville campus despite tle fact that Virginia operated other universities that were either coeducational or open exclusively to women). But see Vorcliheimer v. School Dist. of Philadelphia, 532 F.2d 880 (3d Cir. 1976) (holding constitutional separate but equal all-male and all-female public high schools), aff'd by an equally divided Court, 430 U.S. 703 (1977). See generally Harzenski \& Weckesser, The Case for Strictly Scrutinizing Gender-Based Separate But Equal Classification Schemes, 52 TEMP. L.Q. 439 (1979).

25. See supra notes $16-18$ and accompanying text.

26. See supra text accompanying notes 14-15 \& 19-22.

27. Comment, supra note 12 , at 442 . 
to suppose that sexual mtegration would detract from that atmosphere. Men and woinen live, play, and eat together in families, in college dormitories, and throughout adult life. This lifetime integration strongly suggests that men and women would be able to coexist beneficially in sexually integrated CSO's. ${ }^{28}$

Nevertheless, some critics have contended that college-age men and women are too immature to handle the sexual pressure tliat may accompany CSO integration. ${ }^{29}$ But since the sexes already enjoy a high degree of interaction on most campuses, integrating CSO's is unlikely to noticeably increase such pressure. Instead, integration may lielp teach young men and women to view one another as complete human beings rather than merely as potential sexual partners. ${ }^{30}$ Living togetlier on a daily basis should encourage meinbers of both genders to accept one another as social and intellectual equals. ${ }^{31}$

Although the existing evidence is sparse and anecdotal, it does suggest that integrated CSO's are a viable alternative to the single-sex version. At Princeton University, for example, over half of the upperclass students are meinbers of coeducational CSO's. ${ }^{32}$ Sexually integrated CSO's have enjoyed a measure of success at other colleges and umiversi-

28. The argument against integrating CSO's is based, at least in part, on the notion that men and women have different personality traits. As a gross generalization, this notion derives some support from psychological theories about sex-hinked attributes. See Rhode, supra note 7, at 119-20 \& nn.68, 70.

A tendency toward personality differences among men and women as groups, however, does not mean that the individual men and women who wish to join CSO's will be incompatible. Indeed, the vague and general nature of sex-linked traits suggest that gender is a "crude proxy" for specific attitudinal characteristics. Id. at 119. Meetings, conversations, and parties are much more accurate screening proeedures for determining compatibility than impersonal blanket judgments based on gender.

29. The sexual immaturity argunent is quite similar to the arguments made 20 years ago against the integration of colleges and universities. See id. at 134 (noting that the president of Harvard University believed that integration would result in insatiable carnal appetites and that other educators feared decline in academic performance).

30. See id. at 142 (arguing that coeducational settings inay help erode the tendency of collegeage men to regard women as "sex objects").

31. Living together should not create significant problems regarding bodily privacy. Members of sexually integrated CSO's can protect their bodily privacy by using single-sex bedrooms and bathrooms. For more thorough discussion of this point, see infra text accompanying notes 283-86.

32. As of 1984, 13 CSO's were affiliated with Princcton University. Referred to as "eating clubs," Princeton's CSO's differ from most university fraternities and sororities because few members reside at them. Instead, almost all eating club members take their meals and socialize at their respective clubs while living in university donnitories.

Of Princeton's 13 eating clubs, 10 were coeducational and three were all-male in 1984. Approximately 1200 juniors and seniors were members at the integrated clubs, and approximately 100 students belonged to each of the all-male clubs. Frank v. Ivy Club, Nos. PL 05-1678, 05-1679, 05-1680, at 4-5, 12, 17, 23 (N.J. Dep't of Law \& Public Safety, Div. on Civil Rights, Finding of Probable Cause, Feb. 6, 1986). For a further description of the CSO system at Priuceton, see Comment, supra note 12 , at 426 n.2, 428 n. 10 . 
ties as well..$^{33}$

These examples indicate that integrated CSO's can provide students with camaraderie, cohesiveness, and the other benefits traditionally associated with CSO membership. ${ }^{34}$ Opening membership to both genders does not necessarily deprive CSO's of control of their membership selection process. Integrated CSO's are still able to choose new members on the basis of relevant characteristics such as congeniality and compatibility. Dual-sex membership pohicies simply enable members to choose their new friends on the basis of personal qualities independent of gender. ${ }^{35}$ Hence, integrated CSO's can yield the same social benefits as single-sex CSO's without the harms of gender stereotyping and discrimination. ${ }^{36}$

\section{II}

\section{State Public Accommodations Statutes}

The most generally applicable means for attacking single-sex CSO's are state statutes prohibiting gender-based discrimination in places of public accommodation. ${ }^{37}$ These state public accommodations statutes often are broader in scope than title II of the federal 1964 Civil Rights Act. ${ }^{38}$ Unlike the federal act, which is constrained by the coinunerce

33. For instance, two of the CSO's operating at Stanford University are coeducational. See Conklin \& Cole, Paper Reviews Fraternities and Sororities at Stanford, Campus Report, Oct. 12, 1983, at 15, col. 1, and 17, col. 2.

34. Comment, supro note 12, at 442; see also Rumsey, Legal Aspects of the Relationship Between Fraternities and Public Institutions of Higher Education: Freedom of Association and Ability to Prohibit Campus Presence or Student Membership, 11 J.C. \& UNIv. L. 465, 478 (1985).

35. See Burns, supra note 14 , at 351 \& n.107.

36. This Comment does not address the wider debate of whether CSO's, regardless of their membership policies, are a worthwhile institution. Critics of CSO's generally assail thesc organizations as ehitist, juvenile, and immical to the academic goals of higher education. In contrast, supporters argue that CSO's provide an atmosphere of stability and cohesiveness in college students' difficult transition from the parental home to independence. See Comment, supra note 12, at 442.

Whatever the merits of this debate, it does not lend itself to legal analysis. An institutional valuation of CSO's is better left to sociological and psychological scholars. Of course, some of the legal issues mvolved in integrating CSO's are also relevant to the legality of abolishing CSO's. See infra text accompanying notes 158-208 (arguing that CSO's are not the type of organization protected by the constitutional freedoms of association); $c f$. Waugh v. Board of Trustees, 237 U.S. 589 (1915) (holding that the University of Mississippi could constitutionally prohibit its students from becoming fraternity members).

37. A typical state public accommodations statute reads as follows:

All persons shall have the opportunity to obtain employinent, and to obtain all the accommodations, advantages, facilities, and privileges of any place of public accommodation, publicly assisted housing accommodation, and other real property without discrimination because of race, creed, color, national origin, ancestry, age, marital status or sex, subject only to conditions and limitations applicable alike to all persons. This opportunity is recoguized as and declared to be a civil right.

N.J. STAT. ANN. § 10:5-4 (West 1976).

38. 42 U.S.C. $\$ 2000 \mathrm{a}$ (1982). 
clause of the Constitution, ${ }^{39}$ these state statutes can reach establishments that are not closely connected to interstate commerce. ${ }^{40}$ Furthermore, of the forty state public accommodations statutes, ${ }^{41}$ at least thirty-four explicitly prohibit discrimination on the basis of sex. ${ }^{42}$ In contrast, the federal act only prohibits discrimination on the grounds of race, color, religion, and national origin. ${ }^{43}$

To apply these state statutes to single-sex CSO's, two conditions must be met. The court must first determine that the CSO is a "place of accommodation." Second, since inany state public accommodations laws exempt private clubs from coverage, ${ }^{44}$ the court must also find that the CSO is a place of public accommodation. This Part discusses the application of current state public accommodations laws to simgle-sex CSO's. Section A exammes two common types of public accommodations laws and argues that both types define "public accommodations" broadly enough to encompass CSO's. Section B then details a list of factors that courts typically use to distimguish "bona fide private clubs" from "places of public accommodation." Applying these factors to CSO's, this Comment concludes that CSO's should be considered places of public accommodation rather than private clubs.

\section{A. The Scope of Public Accommodations Laws}

Most state public accommodations statutes fall into one of two major categories. Statutes of the first type contain a specific hist of those establishments considered to be places of public accommodation. ${ }^{45}$ Such

39. 42 U.S.C. § 2000a(c); see Daniel v. Paul, 395 U.S. 298 (1969); Katzenbach v. McClung, 379 U.S. 294 (1964).

40. See, e.g., Curran v. Mount Diablo Council of the Boy Scouts of America., 147 Cal. App. 3d 712 , 195 Cal. Rptr. 325 (1983) (finding Boy Scouts organizations to be "business establishments" and, as such, places of public accommodation), appeal dismissed, 468 U.S. 1205 (1984); Darius v. Apostolos, 68 Colo. 323, 190 P. 510 (1920) (finding shoeshine stand to be place of public accommodation); Vidrich v. Vic Tanny Int'l, 102 Mich. App. 230, 301 N.W.2d 482 (1980) (finding health club to be place of public accommodatiou); Human Relations Comm'n v. Loyal Order of Moose, Lodge No. 107, $448 \mathrm{~Pa} .451,294$ A.2d 594 (finding fraternal men's club to be place of public accommodation under state law, but not under federal law), appeal dismissed, 409 U.S. 1052 (1972).

41. These statutes are listed in Comment, The Unruh Civil Rights Act: An Uncertain Guarantee, 31 UCLA L. REV. 443, 445 n.15 (1983).

42. The statutes specifically prohibiting gender discrimination are listed in Note, $A$ Proposed Analysis for Gender-Based Practices and Public Accommodations Laws, 16 U. Mich. J.L. ReF. 135, 137 n.19 (1982).

43. 42 U.S.C. $\$ 2000 \mathrm{a}$ (a) (1982); see also Comment, supra note 41 , at $446-47$.

44. See Comment, supra note 41 , at 459 n.87 (listing those statutes that exempt private clubs); see also Project, Discrimination In Access to Public Places: A Survey of State and Federal Public Accommodations Laws, 7 N.Y.U. Rev. L. \& Soc. Change 215, 250 n.251 (1978) (providing a similar, but less current, list).

45. See, e.g., Colo. Rev. Stat. § 24-34-601(1) (1982), ME. Rev. Stat. ANN. tit. 5, § 4553.8 (1987); OHlo REV. CODE ANN. § 4112.01(I) (Baldwin 1977). For a more comprehensive list of such statutes, see Comment, supra note 41 , at 448 n.28. 
lists are typically illustrative rather than exhaustive. ${ }^{46}$ For example, the New Jersey Law Agamst Discrimination states that " '[a] place of public accommodation' shall mclude, but not be limited to: any tavern, roadhouse, hotel, motel, . . . restaurant, eating house, ... motion-picture house, music hall, . . . college and university . . . ."47

The second type of public accommodations statute does not contain an illustrative list. Instead, the scope of these statutes is defined through broad, descriptive phrases. ${ }^{48}$ California's Unruh Civil Rights Act is an example. It provides that "All persons . . . are entitled to the full and equal accommodations, advantages, facilities, privileges, or services in all busmess establishments of every kind whatsoever."49

\section{Illustrative List Statutes}

Where the relevant state's public accommodations statute contains an illustrative hist, a plaintiff challenging CSO membership policies sliould pursue a two-step strategy. First, the plamtiff should try to show that the CSO comes under the explicit wordmg of the statute. This argument was successful in a recent case brought against three all-male CSO's affiliated with Princeton University. ${ }^{50}$ In that case, a female student contended that the refusal of the CSO's to admit women as members violated New Jersey's Law Against Discrimmation. ${ }^{51}$ After eight years of litigation, the New Jersey Division on Civil Riglits found that the CSO's

46. Comment, supra note 41 , at 448 n.28. But see MD. ANN. CoDE art. 49B, $\S 5$ (Supp. 1985) (ostensibly containing an exhaustive hist of all establishments defined as public accommodations); N.H. Rev. Stat. ANN. § 354-A:3(IX) (1955) (same).

47. N.J. Stat. ANN. § 10:5-5(1) (West Supp. 1987) (emphasis added).

48. See, e.g., Ariz. Rev. Stat. ANN. § 41-1441.2 (1956); ConN. Gen. Stat. ANN. § 46a63(1) (West 1958); KaN. Stat. ANN. § 44-1002(h) (1986). For a more comprehensive list of such statutes, see Comment, supra note 41 , at 448 n.28.

49. CaL. Civ. CODE $\S 51$ (West 1982) (emphasis added). In a recent case, the United States Supreme Court declined to reach the merits of a void-for-vagueness challenge to this statute. Board of Directors of Rotary Int'1 v. Rotary Club, 107 S. Ct. 1940, 1948 (1987) (upholding the application of $\S 51$ to Rotary clubs). In a similar case, the Court held that a Minnesota statute that defines a public accommodation as a "business accommodation, refreshment, entertainment, recreation, or transportation facility of any kind . . . whose goods, services, facilities, . . . are . . . available to the public," was not unconstitutionally vague or overbroad. Roberts v. United States Jaycees, 468 U.S. 609, 629-31 (1984) (upholding Minnesota's application of its public accomnodations law to the allmale membership policies of Jaycees clubs).

50. For a description of Princeton's CSO's at the time of this complaint, see supra note 32.

A similar complaint has been filed against an all-male eating club associated with Harvard Umiversity. While Harvard severed all formal relationships with nine eating clubs due to the clubs' refusal to admit women, these clubs are composed exclusively of Harvard students and Harvard alumni. The complaint was filed by a female undergraduate at Harvard who claims that the clubs' membership policies illegally deny her access to the clubs' libraries, meal services, and professional networks. The Massachusetts Commission Against Discrimination has agreed to investigate the case. See N.Y. Times, Dec. 27, 1987, § 1, pt. 2, at 43, col. 1.

51. Frank v. Ivy Club, Nos. PL 05-1678, 05-1679, 05-1680, at 1 (N.J. Dep't of Law \& Public Safety, Div. on Civil Rights, Finding of Probable Cause, Feb. 6, 1986). 
were places of public accommodation and ordered them to begin admitting females. ${ }^{52}$ In so finding, the Division noted that New Jersey's definition of public accommodation mcludes "any restaurant, eating liouse, or place where food is sold for consumption on the premises." 53 Simce the challenged CSO's sold meal contracts and provided dining facilities to their members, the Division ruled that they "clearly fit" within the statute's explicit definition. ${ }^{54}$ Other jurisdictions have also passed public accommodations statutes covering clubs tliat provide regular meal services. $^{55}$

Where a plaintiff cannot convince the court that the relevant statute expressly covers CSO's, she still may be able to show implicit coverage. In interpretimg the scope of public accoininodations laws containing illustrative hists, courts have often apphied the ejusdem generis rule of statutory construction. Under this rule, courts determine whether an entity is a "place of public accommodation" by comparing it to the establishments explicitly histed in the statute. ${ }^{56}$ If the challenged entity is sufficiently similar to a listed estabhishinent and is not exphicitly exempted from coverage, then the court will consider it to be a place of public accommodation. 57

CSO's are similar to at least three types of estabhishments frequently covered by state public accommodations statutes. First, by serving meals to their members, CSO's are the functional equivalent of restaurants and eating houses. ${ }^{58}$ In addition, most CSO's offer their members housing on

52. After this decision, one of the challenged CSO's agreed to admit females. Comment, supra note 12, at $426 \mathrm{n} .2$. The Division of Civil Rights has permitted the other two challenged CSO's to delay their admission of women pending the outcome of their court appeal. PRINCETON ALUMNI WEEKLY, June 10, 1987, at 16.

53. N.J. StAT. ANN. § 10:5-5(1) (West Supp. 1987).

54. Frank, Nos. PL 05-1678, 05-1679, 05-1680, at 36.

55. See New York State Club Ass'n v. City of New York, 69 N.Y.2d 211, 215-16, 505 N.E.2d 915, 916, 513 N.Y.S.2d 349, 351 (upholding a New York City ordinance that applies New York State's public accommodations statute to any club that has over $\mathbf{4 0 0}$ members, provides regular meal service, and accepts dues payments from business enterprises), prob. juris. noted, $108 \mathrm{~S}$. Ct. 62 (1987); see also L.A. Daily J., July 1, 1987, at 9, col. 3, and S.F. Examiner, Nov. 10, 1987, at A1, col. 5 (describing the enactment of similar ordinances in Los Angeles and San Francisco).

56. Comment, supra note 41 , at 449 n.31. For a more detailed explanation of the ejusdem generis rule, see 3 J. SuTherland, STATUTES AND STATUtory Construction $\$ 47.17$ (4th ed. 1984).

57. See, e.g., Darius v. Apostolos, 68 Colo. 323, 327-28, 190 P. 510, 511 (1920) (holding that shoeshine stand is place of public accommodation because it provides personal grooming service much like a barbershop); $c f$. United States Jaycees v. Richardet, 666 P.2d 1008, 1012 (Alaska 1983) (holding that Jaycees clubs are not plaees of public accommodation because they have no fixed geographical situs, unlike all the establishments enumerated in Alaska's public accommodations statute).

58. Most public accommodations statutes prohibit discrimination in such eating establishments. See, e.g., IDAHo CODE § 18-7302(e) (1987); NEB. REV. STAT. § 20-133 (1983); WASH. REV. CODE ANN. $\$ 49.60 .030$ (Supp. 1987). For a more comprehensive list of the types of establishments covered by individual state statutes, see Project, supra note 44, at 290-91. 
a semester-by-semester basis. Hence, like hotels, apartments, and other forms of housmg typically included in public accommodations statutes, ${ }^{59}$ CSO's provide mdividuals with shelter. Finally, and perhaps most significantly, CSO's have many of the characteristics of places of entertainment. They generally grant their inembers access to nuinerous sources of recreation, such as pool tables, ping-pong tables, and VCR's. Such services make CSO's analogous to pool halls, taverns, movie theatres, and other places of entertainment that states have defined statutorily as public accoinmodations. ${ }^{60}$ These three functional similarities provide a basis for finding that under many state statutes containing illustrative lists, CSO's are places of public accoinmodation.

\section{Descriptive Phrase Statutes}

The second type of state public accommodations statute contains only a broad, descriptive phrase to define the covered establishments. Under such a statute, a plaintiff challenging CSO membership policies inust establish that the state legislature intended its broad description to include CSO's. Thus, legislative history is quite inportant in determining the scope of such statutes. For example, in Isbister v. Boys' Club, ${ }^{61}$ the Cahforma Supreme Court had to decide whether the all-male membership policies of a charitable organization's community facility violated Califorma's prohibition of sex discrimination "in all business establishments of every kind whatsoever." 62 The court noted that a series of amendments to Cahiforma's public accommodations law had gradually broadened the law's scope. ${ }^{63}$ Thus, despite the defendant's nonprofit status, the court ruled that the club's recreational facilities made it a "place of ainusement" and, as such, a business establishment. ${ }^{64}$

59. See, e.g., PA. STAT. ANN. tit. 43, § 954(1) (Purdon Supp. 1987) (prohibiting discrimination by "inns, taverns, roadhouses, hotels, motels, whether conducted for the entertainment of transient guests or for the accommodation of those seeking health, recreation, or rest").

However, some state public accommodations laws explicitly permit establishments to rent rooms exclusively to persons of the same sex. See, e.g., KY. REV. STAT. ANN. $\$ 344.145(2)$ (b) (Michic/Bobbs-Merrill 1986); Mass. ANN. Laws ch. 272, §92a (Law. Co-op. 1980); Mich. CoMP. LAwS ANN. § 750.146 (West Supp. 1987).

60. See, e.g., AlASKa STAT. $\S 18.80 .300(12)$ (1983); IDAHO CODE $§ 18-7302(e)$ (1987); NEB. REV. STAT. § 20-133(4) (1983).

A few state statutes distinguish between places of entertainment and places of amusement, defining only the former as places of public accommodation. This distinction rests on the difference between places where one passively watches entertainment, such as movie theaters, and places where one actively participates in games of amusement, such as roller-skating rinks. See Project, supra note 44 , at $248-49$.

61. 40 Cal. 3d 72, 707 P.2d 212, 219 Cal. Rtpr. 150 (1985).

62. CAL. Civ. CoDE $\S 51$ (West 1982).

63. Isbister, $40 \mathrm{Cal} .3 \mathrm{~d}$ at 78-79, $707 \mathrm{P} .2 \mathrm{~d}$ at 215-16, $219 \mathrm{Cal}$. Rptr. at 153-54.

64. Id. at 82-84, 707 P.2d at 217-19, 219 Cal. Rptr. at 155-57; see also Curran v. Mount Diablo Council of the Boy Scouts of America, 147 Cal. App. 3d 712, 195 Cal. Rptr. 325 (1983) (holding that Boy Scouts organizations are "business establishments" and, as such, cannot discriminate on the 
The Minnesota Supreme Court also relied on legislative intent in interpreting Minnesota's Human Riglits Act, which forbids gender discrimmation in "a busmess . . . facility of any kind . . . whose goods, services, facilities, [etc.] are . . made available to the public."65 In United States Jaycees v. McClure, ${ }^{66}$ the court lield that the Act applied to the Jaycees because amendments to the statute had broadened its scope to include all business facilities open to the public. ${ }^{67}$ Although the Jaycees are a nonprofit organization, the court ruled that they operate as a business because they sell inemberships that members buy for the "privileges and advantages of inaking contacts witl others." 68

In litigation under a broad statutory definition of public accommodations, a plaintiff inay benefit if the relevant state has enacted a constitutional equal riglits amendment. Sixteen state constitutions contain equal rights amendments, ${ }^{69}$ which generally provide that "Equality of rights under the law shall not be abridged or demied because of sex."70 The purpose of sucl provisions is to promote gender equality. ${ }^{71}$ These provisions slould encourage courts to apply statutes prohibiting sex discrimination in a broad inanner. However, while at least one state court has followed this approach, ${ }^{72}$ inost courts have treated equal riglits amendinents as being analytically distinct from public accommodations statutes. ${ }^{73}$

basis of homosexuality), appeal dismissed, 468 U.S. 1205 (1984). But see Schwenk v. Boy Scouts of America, 275 Or. 327, 551 P.2d 465 (1976) (holding that the Boy Scouts did not have to accept female applicants because Oregon's Public Accommodations Act applied only to commercial enterprises and not to nonprofit volunteer organizations).

65. MinN. Stat. ANN. $§ 363.01$, subd. 18 (West Supp. 1987).

66. 305 N.W.2d 764 (Minn. 1981).

67. Id. at $766-68$.

68. Id. at 769.

69. ALASKA CONST. art. I, $\S 3$; Colo. Const. art. II, § 29; ConN. ConsT. art. I, § 20; Haw. CONST. art. I, $\S 3$; ILL. CONST. art. I, $\S 18$; LA. CONST., art. I, $\S 3$; MD. CONST. Declaration of Rights art. 46; MASs. CoNST. pt. 1, art. I; MoNT. CoNST. art. II, § 4; N.M. CoNST. art. II, § 18; PA. CONST. art. I, § 28; TEX. ConST. art. I, § 3a; UTAH CoNST. art. IV, § 1; VA. ConST. art. I, §11; WASH. CONST. art. XXXI, § 1; WYo. CoNST. art. I, § 3, art. VI, §1.

70. MD. CONST. Declaration of Rights art. 46.

71. Harzenski \& Weckesser, supra note 24, at 443.

72. See Peppin v. Woodside Delicatessen, 67 Md. App. 39, 46-47, 506 A.2d 263, 267 (1986) (interpreting county's public accommodations ordinance in light of Maryland's equal rights amendment and finding no discretion to balance gender discrimination against other social concerns); cf. Koire v. Metro Car Wash, 40 Cal. 3d 24, 37, 707 P.2d 195, 202, 219 Cal. Rptr. 133, 140 (1985) (noting California's quick ratification of the proposed federal equal rights amendment in holding that California's public accoinınodations statute prohibited a nightclub and a carwash from offering discounts only to woinen).

73. See, e.g., United States Jaycees v. Richardet, 666 P.2d 1008, 1011-14 (Alaska 1983) (holding that Jaycees' refusal to adnit woinen as members violated neither Alaska's public accoinmodations statute nor its constitutional equal rights provision); United States Jaycees v. Massachusetts Comın'n Against Discrimination, 391 Mass. 594, 609 n.9, 463 N.E.2d 1151, 1160 n.9 (1984) (holding that Jaycees clubs are not "places" of public accommodation under Massachusetts 
Whatever the weight accorded an equal rights amendment, a plaintiff should be able to show that CSO's fall within the general definition of "business facility" contained in inany state public accommodations statutes. CSO's display a number of the characteristics that courts consider relevant in interpreting the scope of such statutes. Both the California and Minnesota Supreme Courts have held that their respective state statutes are broad enough to encompass nonprofit entities that exhibit "businesslike attributes." ${ }^{74}$ Like the Jaycees clubs in Minnesota, ${ }^{75}$ CSO's actively recruit new inembers, charge thein substantial fees, and offer them access to social gatherings, recreational opportunities, and business contacts. ${ }^{76}$ Furthermore, like the community Boys' Club in California, CSO's provide their inembers with recreational facilities and thereby fall into the subcategory of business establishments known as "places of ainuseinent."77 By providing meinbers with services in exchange for dues, CSO's operate very inuch like traditional businesses. Indeed, as Judge Mosk declared in his dissent in Isbister:

There is no way any court can read the rationale of the majority opinion and yet deny the right of a male student to join a sorority, or a female student to become a fraternity member. If the Boys' Club of Santa Cruz is a business because it operates a gymnasium and swimming pool, a fortiori sororities and fraternities, which provide and charge for housing accommodations and eating facilities, are business establishments. ${ }^{78}$

Under one or more of these arguments, a plaintiff should be able to establish that CSO's are withm the scope of many states' public accominodations statutes. While these statutes have been subject to widely varied interpretations in different states, ${ }^{79} \mathrm{CSO}$ 's are substantially similar

law, but deferring question of whether Jaycees' all-male membership policies violate Massachusetts' equal rights amendment).

74. Isbister v. Boys' Club, 40 Cal. 3d 72, 82, 707 P.2d 212, 218, 219 Cal. Rptr. 150, 156 (1985) (described supra in text accompanying notes 61-64); United States Jaycees v. McClure, 305 N.W.2d 764, 768-69 (Minn. 1981) (described supra in text accompanying notes 65-68). However, the highest court of at least one other state has interpreted a broad statutory definition of public accommodations not to include nonprofit business establishments. See Schwenk v. Boy Scouts of America, 275 Or. 327, 334-36, 551 P.2d 465, $468-69$ (1976) (described supra in note 64).

75. McClure, 305 N.W.2d at 771.

76. See supra text accompanying notes 9-10 \& 14-15.

77. Isbister, $40 \mathrm{Cal} .3 \mathrm{~d}$ at $81-84,707$ P.2d at 217-19, 219 Cal. Rptr. at 155-57.

78. Id. at 94, 707 P.2d at 227, 219 Cal. Rptr. at 165 (Mosk, J., dissenting).

79. Compare United States Jaycees v. McClure, 305 N.W.2d 764 (Minn. 1981) (holding Jaycees to be place of public aceommodation under Minnesota law) with United States Jaycees v. Richardet, 666 P.2d 1008 (Alaska 1983) (holding Jaycees not to be place of public accommodation) and United States Jaycees v. Massachusetts Comm'n Against Discrimination, 391 Mass. 594, 463 N.E.2d 1151 (1984) (same). Compare also Curran v. Mount Diablo Council of the Boy Scouts of America, 147 Cal. App. 3d 712, 195 Cal. Rptr. 325 (1983) (holding Boy Scouts organizations to be places of public accommodation), appeal dismissed, 468 U.S. 1205 (1984) with Schwenk v. Boy Scouts of America, 275 Or. 327, 551 P.2d 465 (1976) (holding Boy Scouts organizations not to be places of public accommodation). 
to establishments that most states consider to be places of accommodation. Under statutes containing nonexhaustive, illustrative hists of covered establishments, courts should find CSO's to be places of accommodation on the basis of their functional similarity to eating houses, places of lodging, and/or places of entertainment. Under statutes containing only a general description of the covered estabhishments, CSO's should be included because of their businesslike characteristic of selling memberships in exchange for services.

Although CSO's are quite similar to many statutorily defined places of accommodation, they also exhibit some of the characteristics typically associated with private clubs. Since private clubs generally are exempt from public accommodations laws, ${ }^{80}$ the next section analyzes whether CSO's persuasively can claim to be private clubs.

\section{B. CSO's As Places of Public Accommodation}

A typical statutory exemption for private clubs provides that "Nothing [in this public accommodations act] shall be construed to include or to apply to any institution, bona fide club, or place of accommodation, which is in its nature distinctly private." 81 Even in the absence of such statutory language, some courts have found a private club exemption to be implied in their state's statute. ${ }^{82}$

State law private club exemptions usually are similar to the private club exemption contained in title II of the federal Civil Rights Act. ${ }^{83}$ Although Congress enacted this exemption with an eye toward preserving the right of free association, ${ }^{84}$ the Constitution does not mandate such an exemption with respect to CSO's. As organizations, CSO's are neither intimate nor expressive enough to warrant constitutional protection of their membership policies. ${ }^{85}$

80. See, e.g., IDAHO CODE § 18-7302(e) (1987); N.J. STAT. ANN. § 10:5-5(l) (West Supp. 1987); OR. Rev. StAT. § 30.675(2) (1977); see also Project, supra uote 44, at 250 n.251 (listing statutes containing explicit private club exemptions).

81. N.J. Stat. ANN. § 10:5-5(l) (West Supp. 1987).

82. See, e.g., Gardner v. Vic Tanny Compton, Inc., 182 Cal. App. 2d 506, 6 Cal. Rptr. 490 (1960) (holding private gymnasium open only to members and guests not to be public accommodation although California's public accommodations statute lacked an explicit private club exemption).

83. 42 U.S.C. $\$ 2000 \mathrm{a}$ (e) (1982) ("The provisions of this subchapter shall not apply to a private club or other establishment not in fact open to the public, except to the extent that the facilities of such establishment are made available to the customers or patrons of an establishment within the scope of subsection (b) of this section.")

84. See 1964 U.S. CODE CONG. \& ADMIN. News 2355, 2495 (several members of Congress publicly stated that "where freedom of association might logically come imto play as in cases of private organizations, title II quite properly exempts bona fide private clubs and other establishments").

85. See infra text accompanying notes 158-208; $c f$. Sigma Chi Fraternity v. Regents of Univ. of Colo., 258 F. Supp. 515 (D. Colo. 1966) (holding that fraternity had no constitutional right to 
Nor does title $\mathrm{IX}^{86}$ preempt state efforts to regulate the membership policies of CSO's. Although title IX specifically exempts fraternities and sororities ${ }^{87}$ from its prohibition of federal funding to educational organizations that discriminate on the basis of gender, ${ }^{88}$ it serves merely to establish a minimum level of sexual integration. Federal law preempts state legislation only if the state legislation presents an unambiguous obstacle to the "full purposes and objectives of Congress." 89 Since state public accommodations laws serve to bolster, rather than to interfere with the antidiscrimination principles of title IX, individual states may apply these laws to federally exempt organizations such as CSO's. ${ }^{90}$

While title IX should not affect state attempts to regulate the membership policies of CSO's, title II of the federal Civil Rights Act might influence these attempts. Although state public accommodations laws and the federal Act are analytically distinct, many state courts have looked to title II decisions for guidance in determining the scope of private club exemptions. ${ }^{91}$ The federal courts have analyzed a wide variety of criteria to distinguish private organizations from places of public accommodation. These criteria involve both imternal and external factors. Internal factors include such aspects as the selectivity of member-

discriminate against blacks in membership selection); Project, supra note 44, at 251 (arguing that private men's clubs have no constitutional right to discriminate against women).

86. 20 U.S.C. $\$ 1681(a)(1982)$.

87. 20 U.S.C. \& 1681(a)(6) (1982); see also 120 Cong. Rec. 39,993 (1974) (statement of Senator Birch Bayh) ("Greek organizations, inuch like the single-sex college, must not be destroyed in misdireeted effort to apply Title IX.").

88. The Supreme Court has held that title IX applies on a program-by-program basis. Under this interpretation, if a program or organization sponsored by a university discriminates on the basis of gender, the federal financial assistance received by that specific program can be terminated, but the federal finacial assistance received by the university as a whole cannot be terminated. See Grove City College v. Bell, 465 U.S. 555, 570-74 (1984).

However, Congress recently passed a bill designed to change this program-specific interpretation. This bill, entitled the Civil Rights Restoration Act, prohibits all federal funding to certain institutions, including universities, where any component of that institution practices gender or any other forbidden form of discrimination. Although President Reagan vetoed this bill, Congress overrode his veto. See N.Y. Times, Mar. 23, 1988, at 1, col. 6.

89. Perez v. Campbell, 402 U.S. 637, 649 (1971); see also Florida Lime \& Avocado Growers v. Paul, 373 U.S. 132, 146-47 (1963) (state regulation not preempted unless it creates an "irreconcilable conflict with the federal regulation [or] . . . Congress has nevertheless ordained that the state regulation shall yield").

90. See, e.g., Isbister v. Boys' Club, 40 Cal. 3d 72, 90 n.21, 707 P.2d 212, 224 n.21, 219 Cal. Rptr. 150, 162 n.21 (1985) (requiring Boys' Club to admit females despite its exemption from title IX, 20 U.S.C. $\$ 1681(\mathrm{a})(6)(B)$ (1982)); Curran v. Mount Diablo Council of the Boy Scouts of America, 147 Cal. App. 3d 712, 195 Cal. Rptr. 325 (1983) (applying California's public accommodations statute to Boy Scouts despite their exemption from title IX).

91. See, e.g., United States Jaycees v. McClure, 305 N.W. 2d 764 (Minn. 1981); Clover Hill Swimming Club, Inc. v. Goldsboro, 47 N.J. 25, 219 A.2d 161 (1966); Kiwanis Club v. Board of Trustees of Kiwanis Int'l, 83 Misc. 2d 1075, 374 N.Y.S.2d 265 (1975), aff'd, 52 A.D.2d 906, 383 N.Y.S.2d 383 (1976), aff'd, 41 N.Y.2d 1034, 363 N.E.2d 1378, 395 N.Y.S.2d 633, cert. denied, 434 U.S. 859 (1977). 
ship, ${ }^{92}$ the control of decisionmaking, ${ }^{93}$ the club's historical purpose, ${ }^{94}$ and the club's ineinbership size. ${ }^{95}$ These factors are internal in the sense that they concern the club's relationship to its members. External factors, on the other hand, concern the club's relationship to the outside world. They include the exclusivity of club facilities, ${ }^{96}$ the sources of the club's funding, ${ }^{97}$ and the club's relationship, if any, to other institutions. ${ }^{98}$

CSO's are a hybrid entity. While they maintain many internal pohcies characteristic of private clubs, their external relationships are much more indicative of public facilities. Since the essence of CSO's is their external relationship to colleges and umversities, this Comment argues that courts should define them as places of public accommodation rather than as private clubs.

The strongest argument in support of a CSO's claim to private status is its selectivity in choosmg new members. Most CSO's choose their new ineinbers through a "rush" procedure lasting approximately one week. During this period, current CSO members meet, socialize, and

92. See, e.g., Rogers v. International Ass'n of Lions Clubs, 636 F. Supp. 1476, 1480 (E.D. Mich. 1986) (local Lions chapter not a private club because it accepted almost every male applicant who met minimal standards); Cornelius v. Benevolent Protective Order of Elks, 382 F. Supp. 1182, 1203 (D. Conn. 1974) (local Elks chapter within private club exemption because it had well-defined requirements for membership selection).

93. See, e.g., Daniel v. Paul, 395 U.S. 298, 302 (1969) (water resort club not private because the members did not exercise control over such important decisions as who would become a new member); United States v. Johnson Lake, Inc., 312 F. Supp. 1376 (S.D. Ala. 1970) (water resort club not private where members had no input concerning expenditures).

94. See, e.g., United States v. Richberg, 398 F.2d 523 (5th Cir. 1968) (Dixie Diner Club not private because it had been organized solely to circumvent 1964 Civil Rights Act); Cornelius, 382 F. Supp. at 1203-04 (noting that Elks had been organized originally for purpose of Sunday recreation).

95. See, e.g., Nesmith v. YMCA, 397 F.2d 96, 102 (4th Cir. 1968) (defendant YMCA not private club because it had no limit on membership size); New York State Club Ass'n v. City of New York, 69 N.Y.2d 211, 216, 505 N.E.2d 915, 916, 513 N.Y.S.2d 349, 350 (upholding an ordinance that defines organizations as nonprivate if they have more than 400 members, provide regular meal service, and receive payments from business entities), prob. juris. noted, $108 \mathrm{~S}$. Ct. 62 (1987).

96. See, e.g., Wright v. Cork Club, 315 F. Supp. 1143, 1154-55 (S.D. Tex. 1970) (dining club not private where "regularly used by nonmembers who [were] not bona fide guests"); Commonwealth Human Relations Comm'n v. Loyal Order of Moose Lodge No. 107, $448 \mathrm{~Pa} .451$, 458-59, 294 A.2d 594, 597 (fraternal lodge not private because it regularly opened its dining room and bar to all white guests of members), appeal dismissed, 409 U.S. 1052 (1972).

97. See, e.g., Nesmith, 397 F.2d at 102 (noting that YMCA partially financed by contributions solicited from the general public); Shepherdstown Volunteer Fire Dep't v. West Va. Human Rights Comm'n, 309 S.E.2d 342, 350 (W.Va. 1983) (volunteer fire department place of public accommodation because it received considerable funding from public solicitation and government grants).

98. See, e.g., Franklin v. Order of United Commercial Travelers, 590 F. Supp. 255, 259 (D. Mass. 1984) (fraternal benefit society that offered insurance to policemen but not to policewomen not "purely private" because it was "closely affiliated with city police department"); United States v. Beach Assocs., Inc., 286 F. Supp. 801, 807 (D. Md. 1968) (beach club not private where located on same premises as public food shop and where its tables regularly used by the public shop's customers). 
evaluate prospective inembers. ${ }^{99}$ These screening procedures generally indicate a true selectivity. ${ }^{100}$ Some CSO's, however, adınit all applicants meeting minimal standards, and some even choose new members at random. ${ }^{101}$ CSO's employing such nonselective methods have a much weaker claim to private club status than truly selective CSO's. ${ }^{102}$ Nevertheless, even if a CSO is selective, that characteristic is not itself sufficient to make the organization a "private club" beyond the reach of state pubhic accominodations statutes. ${ }^{103}$

A single-sex CSO can bolster its claim to private club status if its members control the club's decisionmaking. ${ }^{104}$ Undergraduate members of a CSO usually manage the organization's daily activities and meet with alumin members to make more important decisions regarding matters such as facility maintenance and major purchases. The scope of this self-management, however, is constrained by university policy. For example, while undergraduate members may determine which new individuals can join the CSO, they must do so in accordance with university guidelines prohibiting racial and religious discrimination. ${ }^{105}$ Similarly, universities can control how their CSO's induct new inembers, conduct parties, mamtain their preinises, and otherwise affect the university community. ${ }^{106}$ Hence, the members of a CSO do not enjoy as much unfet-

99. Comment, supra note 12 , at 435 .

100. Id. (noting that the all-male CSO's at Princeton University denied membership to over one-half of their applicants).

101. See Frank v. Ivy Club, Nos. PL 05-1678, 05-1679, 05-1680, at 5 (N.J. Dep't of Law \& Public Safety, Div. on Civil Rights, Finding of Probable Cause, Feb. 6, 1986) (noting that most integrated CSO's at Princeton University used lottery system to choose new members).

102. See Rogers v. International Ass'n of Lions Clubs, 636 F. Supp. 1476, 1480 (E.D. Mich. 1986) (local Lions clubs not private because they "engage in intensive and continuous recruitment of new members, $\ldots$ and admit virtually all applicants who meet minimal standards for membership"); United States Jaycees v. McClure, 305 N.W.2d 764, 771 (Minn. 1981) (local Jaycee chapters not private clubs because they emphasize quantity over quality in accepting new members).

103. See Rotary Club v. Board of Directors of Rotary Int'l, 178 Cal. App. 3d 1035, 1058-59, 224 Cal. Rptr. 213, 226 (1986) (local Rotary clubs not private despite selectivity in "limiting membership ... to business and professional leaders in the community"), aff'd, $107 \mathrm{~S}$. Ct. 1940 (1987); Clover Hill Swimming Club v. Goldsboro, 47 N.J. 25, 33-34, 219 A.2d 161, 165 (1966) (swimming faeility not private club despite 400 -family membership limit and requirement that club officials approvc all members); New York State Club Ass'n v. City of New York, 69 N.Y.2d 211, 221, 505 N.E.2d 915, 919-20, 513 N.Y.S.2d 349, 353-54 "selectivity in its membership" does not establish private club status where challenged entity exhibits other characteristics "affected with a public interest"), prob. juris. noted, 108 S. Ct. 62 (1987).

But see Kiwanis Int'l v. Ridgewood Kiwanis Club, 806 F.2d 468 (3d Cir. 1986) (local Kiwanis clubs not public accommodations due to selectivity in choosing new members), reh'g denied, 811 F.2d 247 (1987) (three judges vigorously dissenting). Cf. Jones, supra note 12, at 2 (condemning the Kiwanis court focus on selectivity as "a bit too simplistic an approach to analyzing public accommodations cases").

104. See supra note 93 and accompanying text.

105. See infra text accompanying notes $245-46$.

106. If a CSO refuses to follow university guidelines, the university can apply a variety of sanctions. See, e.g., Sigma Chi Fraternity v. Regents of Univ. of Colo., 258 F. Supp. 515 (D. Colo. 
tered decisionmaking power as truly private organizations.

The historical purpose of CSO's also strengthens their claim of exemption from state public accommodations laws. Unlike clubs that were organized to avoid civil rights legislation ${ }^{107}$ or to make a financial profit, ${ }^{108}$ the traditional purpose of CSO's has been to foster congemiality. ${ }^{109}$ CSO's generally seek to provide a comfortable atmosphere where members can relax and enjoy one another's company. Courts have recognized that congemiality is a legitimate value worthy of some degree of legal protection from government interference. ${ }^{110}$

As a byproduct of their promotion of congemality, CSO's afford their members the opportunity to develop valuable business contacts. ${ }^{11}$ These contacts are the type of informal advantage that women generally lack in the male-dommated business world. Courts ${ }^{112}$ and commentators ${ }^{113}$ have urged that such contacts be made equally available to women in order to help them overcome the current gender gap in employment. ${ }^{114}$ Consequently, the practical status of CSO's as hinks im the "old-boy" power chain undermines the claim that CSO's are private clubs due to their avowed social purpose. ${ }^{115}$

The membership size of CSO's also cuts both ways im the private/ public determination. In 1984-85, the average fraternity chapter consisted of approximately fifty undergraduate students. ${ }^{116}$ Proponents of single-sex CSO's argue that this number is small enough so that members

1966) (upholding university's power to suspend fraternity from pledging new members where fraternity discriminated against blacks).

107. See, e.g., Umited States v. Richberg, 398 F.2d 523 (5th Cir. 1968) (described supra at note 94); United States v. Johnson Lake, Inc., 312 F. Supp. 1376, 1381 (S.D. Ala. 1981) ("club formed for the primary purpose of excluding Negroes on account of their race is not a private club").

108. See, e.g., Daniel v. Paul, 395 U.S. 298, 301 (1968) (water resort club not private where it is "simply a business operated for a profit with none of the attributes of self-government and memberownership traditionally associated with private clubs"); Vidrich v. Vic Tanny Int'l, 102 Mich. App. $230,235,301$ N.W.2d 482, 484 (1980) (health club is public accommodation due to its operation as "profitable commercial enterprise").

109. Comment, supra note 12 , at $435-36$.

110. See Roberts v. United States Jaycees, 468 U.S. 609, 620 (1984); Cornelius v. Benevolent Protective Order of Elks, 382 F. Supp. 1182, 1204 (D. Conn. 1974).

111. See supra note 14 and accompanying text.

112. See Rotary Club v. Board of Directors of Rotary Int'l, 178 Cal. App. 3d 1035, 1055-58, 224 Cal. Rptr. 213, 224-26 (1986), aff'd, 107 S. Ct. 1940 (1987); Kiwanis Club v. Kiwanis Int'l, 52 A.D.2d 906, 916, 383 N.Y.S.2d 383, 393-94 (1976), aff'd, 41 N.Y.2d 1034, 363 N.E.2d 1378, 395 N.Y.S.2d 633, cert. denied, 434 U.S. 859 (1977).

113. Burns, supra note 14, at 322-25; Goodwin, Challenging the Private Clubs, 13 Sw. U.L. REV. 237, 280-84 (1982).

114. See supra note 15 and accompanying text.

115. Cf. Cornelius, 382 F. Supp. at 1204 ("[i]f a lodge were to . . become an establishment where economic opportunity was the attraction, it would cease to be exempt [from public accommodations statutes]").

116. Rumsey, supra note 34 , at 467 n.11. 
form "intimate relationships" which should be protected. ${ }^{117}$ The total meinbership of such CSO's, however, often numbers in the thousands when one includes graduate and honorary meinbers. ${ }^{118}$ Courts should include these alumm meinbers in determining meinbership size because such members usually form committees to supervise the affairs and property of the CSO. ${ }^{119}$ In addition, while alumni members rarely participate in a CSO's day-to-day affairs, they remain entitled to use the CSO's facilities. Thus, despite a CSO's sinall core membership, its active inembership often exceeds 400 people-the number that the United States Supreme Court has suggested as the public/private boundary. ${ }^{120}$

The fact that CSO's rarely operate on a "members-only" basis further undermines their claim of private club status. CSO's generally allow their members to bring guests to almost any club function, including meals, parties, and trips. In addition, since single-sex CSO's usually do not require guests to be formally "sponsored" by a meinber, both male and feinale nonmembers can often be found relaxing on CSO preinises. ${ }^{121}$ This lack of exclusivity undercuts a CSO's claim to privacy because its members cannot legitimately expect their in-club interaction to be confined to the membership. Instead, open guest policies enable almost any student, regardless of gender, to use club facilities and interact with club members. Such accessibility is more indicative of a public place than a private club. ${ }^{122}$

Another compelling reason for finding that CSO's are places of public accommodation is their financial and institutional ties with the outside world. Unlike bona fide private clubs, CSO's often receive a significant percentage of their operating expenses through public funds. One source of this public funding is the housing and meal fees paid by students on financial aid. In general, financial aid consists of a combina-

117. Comment, supra note 12 , at 434.

118. See generally Baird's MANUAL of American College Fraternities (19th ed. 1977).

119. See Comment, supra note 12, at 434 (noting that alumni participate in CSO's through alumni dinners, fundraising, and graduate board governance); see also Frank v. Ivy Club, Nos. PL 05-1678, 05-1679, 05-1680, at 11, 14, 16-17 (N.J. Dep't of Law \& Public Safety, Div. on Civil Rights, Finding of Probable Cause, Feb. 6, 1986) (finding that alumni members played significant role in governing all-male CSO's at Princetou).

120. See Roberts v. United States Jaycees, 468 U.S. 609, 621 (1984) (stating that Minnesota's 400-person Jaycee chapters were too large to be intimate); New York State Club Ass'n v. City of New York, 69 N.Y.2d 211, 216, 505 N.E.2d 915, 916, 513 N.Y.S.2d 349, 350 (upholding an ordinance that classifies clubs with more than 400 members as places of public accommodation), prob. juris. noted, 108 S. Ct. 62 (1987).

121. See Frank, Nos. PL 05-1678, 05-1679, 05-1680, at 35-36.

122. See Commonwealth Human Relations Comm'n v. Loyal Order of Moose, Lodge No. 107, $448 \mathrm{~Pa} .451,458-59,294 \mathrm{~A} .2 \mathrm{~d} 594,598$ (defendant lodge is place of public accommodation under state statute because "[a]ny member of the public . . . may intrude upon the privacy and exclusiveness of the [club] dining room, so long as there is some member of the [club] who will [sponsor him]"), appeal dismissed, 409 U.S. 1052 (1972). 
tion of loans, work-study job funds, and outright grants, all of which are subsidized by the federal or state government. This aid usually includes a budgeted amount for rooin and board, which students often use to help pay for their CSO meal/housing contracts. Soine universities even provide additional financial aid to cover the difference in cost between dorinitory and CSO meal contracts. ${ }^{123}$ CSO's profit from this governmentsubsidized financial aid because soine students could not afford to join a CSO without it. CSO's receive additional financial benefits from their tax-exempt status under federal and state law. ${ }^{124}$ This partial pubhe funding weiglis leavily in favor of finding CSO's to be places of public accoinmodation. ${ }^{125}$ As Judge Friendly observed in a related context, there is a "peculiar offensiveness [in] the state's taxing all citizens for objectives froin the benefits of which a particular category is arbitrarily excluded."126

In addition to their financial relationship with the state, CSO's liave close mstitutional relationships witl universities that furtlier illustrate their public nature. Courts have consistently lield that an entity loses its private club status if it is closely affiliated with a public place. ${ }^{127}$ Assum-

123. Frank, Nos. PL 05-1678, 05-1679, 05-1680, at 18.

124. CSO's are generally exempt from federal taxation under I.R.C. $\S 501(c)(7)$ (1982), which exempts "[c]lubs organized for pleasure, recreation, and other nonprofitable purposes." See Zeta Beta Tau Fraternity, Inc. v. Conimissioner, 87 T.C. 421 (1986). Although Congress has denied this exemption to clubs that discriminate on the basis of race, color, or rehigion, this exemption is still available to single-sex clubs. See I.R.C. $\S 501$ (i) (1982). Similarly, while Maryland and a few other states do not grant tax-exempt status to clubs that discriminate on the basis of gender, most states continue to grant such exemptions. See Burns, supra note 14, at 387 ; Rhode, supra note 7 , at 124.

125. Many coninientators have argued that since tax exemptions are a forn of public finance, entities receiving substantial exemptions should be considered "public." See, e.g., Goodwin, supra note 113, at 259-65; Rhode, supra note 7, at 126 \& n.91. Some courts have considered tax exemptions as a factor in distinguishing public organizatious from private clubs in the context of race discrimination cases. However, most courts have iguored this factor in sex discrimination cases. Compare Jackson v. Statler Foundation, 496 F.2d 623, 629-34 (2d Cir. 1974) (finding role of tax exemptions critical to deternining whether allegedly racially discriminatory organization was "state actor"), cert. denied, 420 U.S. 927 (1975) and McGlotten v. Connally, 338 F. Supp. 448, 460-62 (D.D.C. 1972) (prohibiting certain tax exemptions to racially discriminatory clubs due to the 1964 Civil Rights Act) with New York City Jaycees, Inc. v. United States Jaycees, Inc., 512 F.2d 856, 859 (2d Cir. 1975) (holding that tax exemption granted to all-male Jaycees clubs "does not constitute government 'sponsorship' ") and McCoy v. Schultz, 73-1 U.S. Tax Cas. (CCH) If 9233 (D.D.C. 1973) (finding that tax exemptions granted to the all-male Portland City Club did not make the club a public entity).

126. Powe v. Miles, 407 F.2d 73, 82 (2d Cir. 1968) (described infra note 238).

127. See, e.g., Franklin v. Order of United Commercial Travelers, 590 F. Supp. 255, 259 (D. Mass. 1984) (fraternal benefit society offering insurance to male police officers, but not to female officers, is public acconınıodation where "closely affiliated with city police department"); United States v. Medical Soc'y, 298 F. Supp. 145, 152 (D.S.C. 1969) (hospital not private facility where snack bar and cafe located on hospital premises were plaees of public accommodation); United States v. Beach Assocs., Inc., 286 F. Supp. 801, 807 (D. Md. 1968) (beach club is public accomniodation where located on same premises as public food shop and where its tables used by the food shop's customers); accord Adams v. Miami Police Benevolent Ass'n, 454 F.2d 1315, 1319 (5th 
ing that most colleges and universities are places of public accoinınodation, ${ }^{128}$ this "close affiliation" doctrine should apply to CSO's. CSO's are not isolated organizations. They exist to provide services, facilities, and camaraderie to students attending college. Indeed, many universities would encounter considerable difficulty feeding and housing their entire student body without the presence of CSO's. ${ }^{129}$ In return, CSO's benefit from this relationship by being allowed to recrint members from campus, advertise in umiversity newspapers, and sponsor campus parties. The New Jersey Division on Civil Rights focused on this close affiliation in determining that the all-male CSO's at Princeton Umiversity were places of public accommodation. In ruling that these CSO's were not private clubs, the Division einphasized that the CSO's were "integrally connected [to the university] im a mutually beneficial relationship."130

Umiversities often recognize their special relationship with CSO's through a written agreement. In a typical agreement, the university endorses the signatory CSO as a legitimate student organization by according it "sponsorship" status. ${ }^{131}$ This endorsement usually grants the CSO special privileges, such as access to campus facilities, installation of university phone lines, and the opportumity to sponsor campus activities. ${ }^{132}$ In exchange, the CSO promises to abide by university guidelines regarding matters such as recruitment, hazing, and

Cir.) (prohibiting defendant association from discriminating against black police officers where association was closely associated with city police department), cert. denied, 409 U.S. 843 (1972).

128. Some state statutes specifically include colleges and universities in their illustrative lists of places of public accommodation. See N.J. STAT. ANN. § 10:S-S(1) (West Supp. 1987); see also Peper v. Princeton Univ. Bd. of Trustees, 77 N.J. 55, 67-68, 389 A.2d 465, 471-72 (1977) (upholding the statute's definition of Princeton University as place of public accommodation). Other statutes explicitly declare that colleges and universities are not places of public accommodation. See N.Y. EXEc. LAw §292(9) (McKinney 1982). Moreover, where the public accommodations law contained just a broad description of covered establishments, one state supremc court determined that this law did not apply to colleges and universities. See Human Rights Comm'n v. Board of Regents, 95 N.M. 576, 577, 624 P.2d 518, 519 (1981).

129. Frank v. Ivy Club, Nos. PL 05-1678, 05-1679, 05-1680, at $42-43$ (N.J. Dep't of Law \& Public Safety, Div. on Civil Rights, Finding of Probable Cause, Feb. 6, 1986) (noting the difficulty that Princeton University would experience in feeding its upperclass students if its CSO's were to cease operation).

130. Id. at 35 .

131. See, e.g., University of California at Berkeley, Student Organization SPONSORSHIP AGREEMENT (1986-87) [hereinafter UC-BERKELEY SPONSORSHIP AGREEMENT]; ST. LAWRENCE UNIVERSTTY, STANDARDS FOR RECIPROCAL RELATIONS BETWEEN Fraternities/ SORORITIES AND ST. LAWRENCE UNIVERSITY (1986-87) [hereinafter ST. LAwRENCE UN1V. Reciprocal AGReEment]; see also Conklm \& Cole, supra note 33, at 16, col. 1 (describing the manner by which fraternities and sororities at Stanford Umiversity gain "University recognition" and the significance of that status).

132. See St. Lawrence Univ. Reciprocal Agreement, supra note 131, at 10-12; Conklin \& Cole, supra note 33 , at 16 , col. 1 . 
drinking. ${ }^{133}$

Other factors also illustrate the close affiliation between CSO's and their universities. Some universities hire advisors to act as liaisons between the university and its CSO's. Universities also tend to establish committees, such as interfraternity and panhellenic councils, to oversee and adjudicate nuatters and disputes involving CSO's. Finally, many universities describe their fraternity and sorority systens in their catalogs and brochures. By promoting CSO's as an attractive option for student living arrangements, these universities imphicitly treat their CSO's as a coniponent of the overall university community.

In summary, many state pubhic accommodations statutes seem to require the sexual integration of CSO's. CSO's fall within the reach of such laws in soine states because they sell food, rent shelter, and provide recreational facilities. In other states, they fall within the general scope of these laws because they have the "businesslike attribute" of selling meinberships. Courts should not exeinpt CSO's fron these statutes on the ground that CSO's possess some of the internal characteristics of private clubs. Other characteristics of CSO's, such as their large menibership size, open guest policies, indirect reliance on public financing, and informal proniotion of business contacts contradict the notion that CSO's are private clubs. The close affiliation of CSO's to colleges and universities also severely undercuts their claim to private club exenuption. Hence, single-sex CSO's are vulnerable to legal challenge under the current public accommodations laws of many states.

\section{III}

\section{FREEDOM OF ASSOCIATION ANALYSIS}

Single-sex CSO's are likely to defend against challenges based on public accommodations statutes by contending that the constitutional rights of free association insulate their inembership policies fron governinental interference. ${ }^{134}$ Previous cases have estabhished, however, that CSO's do not have an absolute right of free association. Universities can prohibit CSO's from recruiting students on campus ${ }^{135}$ and front practicing racial discrimination. ${ }^{136}$ Nevertheless, in light of the Suprenie Court's recent decisions regarding associational rights, sonie coinnienta-

133. UC-Berkeley SPONSORShIP AGREEMENT, supra note 131; St. LAWRENCE UNIV. RECIPROCAL AGREEMENT, supra note 131.

134. See, e.g., Comment, supra note 12, at 431-40.

135. See Waugh v. Board of Trustees, 237 U.S. 589, 596-97 (1915) (University of Mississippi could constitutionally prohibit its students from joming fraternities); Webb v. State Univ., $125 \mathrm{~F}$. Supp. 910, 911-12 (N.D.N.Y.) (state universities in New York could constitutionally ban social organizations from having direct or indirect affiliation with any national fraternity or sorority), appeal dismissed, 348 U.S. 867 (1954).

136. See Sigma Chi Fraternity v. Regents of Univ. of Colo., 258 F. Supp. 515 (D. Colo. 1966) 
tors have argued that these rights should protect a CSO's single-sex membership policies. ${ }^{137}$ The purpose of this Part of the Comment is to refute that argument.

The Supreme Court thoroughly examined the scope of associational rights in the case of Roberts $\nu$. United States Jaycees. ${ }^{138}$ The issue in Roberts was whether Minnesota could constitutionally compel its chapters of the United States Jaycees to grant women full membership. ${ }^{139}$ The Court identified two distinct forms of associational rights: the freedom to maintain intimate human relationships, and the freedom to associate for expressive purposes. ${ }^{140}$

The right of intimate association is rooted in the due process clause of the fifth and fourteenth amendments as a "fundamental element of personal hiberty." ${ }^{141}$ The right exists to protect highly personal relationships through which individuals define their own identity and "draw much of their emotional enrichinent." 142 The Roberts Court stated that such intimate relationships are exemplified by the family because "[f]amily relationships . . . involve deep attachments and commitments to the necessarily few other mdividuals with whom one shares not only a special community of thoughts, experiences, and behiefs but also distinctively personal aspects of one's life." 143 Intimate relationships are usually characterized by their sinall size, high degree of selectivity, and seclusion froin others. ${ }^{144}$ Applying these criteria, the Roberts Court held that the Minnesota chapters of the Jaycees were not intimate associations because they contained upwards of 400 inembers, selected members solely on the basis of age and gender, and permitted noninembers of both

(university could constitutionally suspend fraternity from choosing new members where fraternity refused to admit black applicants).

137. Linder, Freedom of Association After Roberts v. United States Jaycees, 82 Mich. L. Rev. 1878, 1886 (1984); Rumsey, supra note 34 , at $478-79$; Comment, supra note 12, at 434-36.

138. 468 U.S. 609 (1984).

139. The bylaws of the Jaycees limited women to associate membership, which prevented them from votimg, holding office, or participating in certain leadership training programs. Id. at 613.

140. Id. at 617-18.

141. Roberts, 468 U.S. at 618 . Since the Constitution does not explicitly mention a right of intimate association, the Supreme Court occasionally has debated the textual source of this right. See Griswold v. Connecticut, 381 U.S. 479, 484-85 (1965) (finding this right in the "penumbras" of the Bill of Rights); id. at 486 (Goldberg, J., concurring) (basing this right on the ninth amendment). The Court currently appears to have concluded that this right is an aspect of personal liberty protected under the due process clause. See Roe v. Wade, 410 U.S. 113, $152-54$ (1973); Linder, supra note 137, at 1884. But see Board of Directors of Rotary Int'l v. Rotary Club, 107 S. Ct. 1940, 1946 (1987) (suggesting that the first amendment protects certain intimate relationships).

142. Roberts, 468 U.S. at 619.

143. Id. at 619-20; see also Moore v. City of E. Cleveland, 431 U.S. 494, 499-500 (1977) (holding unconstitutional zoning regulation that prevented eight-year-old boy from living with his grandmother).

144. Roberts, 468 U.S. at 620. 
sexes to participate in Jaycee activities. ${ }^{145}$

The second type of associational right recognized by the Roberts Court is the freedom of expressive association. This right is protected by the first amendinent because the freedom to speak, worship, and petition the governinent necessarily includes "a correlative freedom to engage $m$ group effort toward those ends." 146 Hence, the Court stated that the first amendment involves a "right to associate with others $m$ pursuit of a wide variety of pohtical, social, econoinic, educational, rehgious, and cultural ends." 147

The Roberts Court also declared that the right of expressive association was not absolute. States can adopt regulations infringing this right m order to promote other important societal values. The Court thus held that Mimnesota's coinpelling interest in eradicating sex discrimination justified the impact of its public accommodations statute on the Jaycees' freedom of expressive association. ${ }^{148}$ The Court's analysis emphasized that Minnesota's statute neither suppressed speech intentionally ${ }^{149}$ nor infringed associational rights more than necessary. ${ }^{150}$ Requiring the Jaycees to give mdividuals of both sexes equal consideration for membership was a minimally mtrusive manner for Minnesota to achieve its compelling goal. Moreover, admitting women as voting members did not seriously burden the Jaycees' expressive rights because the Jaycees failed to persuade the Court that women would "change the message communicated by the group's speech."151

The Court reaffirmed the limited scope of associational rights in Board of Directors of Rotary International v. Rotary Club. ${ }^{152}$ In that

145. Id. at 621 .

146. Id. at 622; see also Linder, supra note 137, at 1884.

147. Roberts, 468 U.S. at 622.

148. Id. at 623 .

149. Id. at 623-24.

150. Id. at $628-29$.

151. Id. at 627. In her concurrence, Justice O'Connor disagreed with the majority's test for determining the extent of the Jaycee's right of expressive association. In her view, the majority test incorrectly focused on the content of the group's message and whether the unwelcome members would change that message. Id. at 632-33 (O'Connor, J., concurring). She advocated instead a "threshold" approach in which a preliminary determination would be made regarding the degree of expressive activity engaged in by the challenged group. She would distinguish between associations "predominantly engaged in expression" and those associations inore properly characterized as "commercial," arguing that regulations infringing on the latter should be subject ouly to a "rational relation" test. Id. at 634-36 (O'Connor, J., concurring). For a more detailed comparison of the majority and the O'Connor approach to the right of expressive association, see Linder, supra note 137, at 1888-97; Note, Roberts v. United States Jaycees: Does the Right of Free Association Imply an Absolute Right of Private Discrimination?, 1986 UTAH L. REv. 373, 385-89.

152. $107 \mathrm{~S}$. Ct. 1940 (1987). The Court currently is considering another case regarding the scope of associational rights. On February 23, 1988, it heard oral arguments in New York State Club Ass'n v. City of New York, 69 N.Y.2d 211, 505 N.E.2d 915, 513 N.Y.S.2d 349 (described supra note 55), prob. juris. noted, $108 \mathrm{~S}$. Ct. 62 (1987). The case involves an ordinance that effectively 
case, Rotary International terminated the charter of a local California chapter that had violated the Rotary constitution by admitting women as members. The local chapter successfully sued for reinstatement on the ground that Rotary's sex-based membership policies violated California's public accommodations statute. ${ }^{153}$ Rotary International argued, however, that California's application of its public accommodations statute unconstitutionally infringed Rotary members' associational rights.

In uplrolding California's decision to apply its public accommodations law to Rotary clubs, the Supreme Court's opinion in Rotary Club largely paralleled its opinion in Roberts. The Court held that local Rotary chapters were not intimate associations because they have no limits on membership size and they experience a high (10\%) annual turnover rate. ${ }^{154}$ The Court also noted that, rather than seeking privacy, Rotary clubs encourage the participation of nonınembers in club activities and often welcoine media coverage of their fundraising events. ${ }^{155}$ Finally, the Court held that although the admission of women might affect sliglitly the local clubs' expressive inessage, that infringement was justified by Califorma's interest in eradicating sex discrimination. ${ }^{156}$ The Court explicitly stated that California has a compelling interest in providing woinen with equal access to "leadership skills and business contacts." 157

\section{A. CSO's Are Not Intimate Associations}

The purpose of the right of intimate association is to protect a sphere of individual autonomy from governmental interference. The Court has inost often applied this right to decisions regarding iinportant fainily matters. For example, the Court has held that this right protects decisions involving "the creation and sustenance of a fainily,"158 and specifically includes the right to inarry, ${ }^{159}$ to use contraceptives, ${ }^{160}$ to terminate a pregnancy, ${ }^{161}$ and to educate one's children. ${ }^{162}$

prohibits clubs from choosing new members on the basis of gender where the club has more than 400 members, provides regular meal service, and accepts payments from business entities. The Court granted certiorari on several issues, including whether the ordinance violates club members' rights of intimate or expressive association. See 56 U.S.L.W. 3203-04 (U.S. Oct. 6, 1987) (No. 86-1836).

153. Rotary Club v. Board of Directors of Rotary Int'l, 178 Cal. App. 3d 1035, 224 Cal. Rptr.

213 (1986), aff'd, 107 S. Ct. 1940 (1987).

154. Rotary Club, $107 \mathrm{~S}$. Ct. at 1946.

155. Id. at $1946-47$.

156. Id. at 1947.

157. Id. at 1948.

158. Roberts v. United States Jaycees, 468 U.S. 609, 619 (1984).

159. Loving v. Virginia, 388 U.S. 1 (1967).

160. Eisenstadt v. Baird, 405 U.S. 438 (1972); Griswold v. Connecticut, 381 U.S. 479 (1965).

161. Roe v. Wade, 410 U.S. 113 (1973).

162. Pierce v. Society of Sisters, 268 U.S. 510 (1925). 
The special constitutional protection accorded to families is well illustrated by a comparison of two cases involving zoning regulations. In Village of Belle Terre v. Boraas, ${ }^{163}$ the Supreme Court upheld a town zoning ordinance that prevented three or more unrelated persons from living together. Although the six unrelated students who challenged the ordinance argued that it infringed their associational rights, ${ }^{164}$ the Court rejected this argument. Instead, the Court upheld the ordinance because it served the legitimate zoning purposes of reducing traffic and noise im residential areas. ${ }^{165}$ In contrast, in Moore v. City of East Cleveland, ${ }^{166}$ the Court struck down a zoning ordinance that operated to prevent certain configurations of relatives from sharing a single dwelling. Despite the city's legitimate zoning interest in preventimg overcrowded housing, minimizing traffic congestion, and avoiding undue financial burden on city schools, ${ }^{167}$ the Court lield the ordinance unconstitutional as applied because it prohibited a grandmother and grandson from livmg in the same home. ${ }^{168}$ The Court explicitly noted the importance of family relationships in its analysis:

[O]ne overriding factor sets this case apart from Belle Terre. The ordinance there affected only unrelated individuals. It expressly allowed all who were related by "blood, adoption, or inarriage" to live together, and in sustaiming the ordinance we were careful to note that it promoted "family needs" and "family values." 169

The relationships formed in single-sex CSO's are not of the same importance as the familial relationships granted constitutional protection. Although one commentator has suggested that CSO's should be protected as "surrogate families" for college students, ${ }^{170} \mathrm{CSO}$ 's do not perform the same functions as families. The family merits a "private realm ... which the state cannot enter" ${ }^{171}$ because it is the vehicle through which people inculcate and pass down their moral and cultural values. ${ }^{172}$ "[T] $]$ he role of the farmily in raising and training successive generations of the species makes it more important . . . than any other

\footnotetext{
163. 416 U.S. 1 (1974).

164. Id. at 7 .

165. Id. at 9 .

166. 431 U.S. 494 (1977).

167. Id. at $499-500$.

168. Id. at 504-06.

169. Id. at 498 (emphasis in original) (quoting Village of Belle Terre v. Boraas, 416 U.S. 1,9 (1974)); see also Karst, The Freedom of Intimate Association, 89 YALE L.J. 624, 629 (1980) (noting that the right of intimate association extends to institutions "in some significant way comparable to a marriage or family situation"); Marshall, supra note 19, at $81-82$ (stating that none of the values underlying the doctrine of intimate association "is present to any significant degree outside familytype relationships").
}

170. Comment, supra note 12, at 436.

171. Prince v. Massachusetts, 321 U.S. 158, 166 (1944).

172. Moore v. City of E. Cleveland, 431 U.S. 494, 503-04 (1977). 
social or legal institution." ${ }^{173}$ In contrast, single-sex CSO's are transient living arrangeinents that seek merely to foster congeniality among unrelated college students, like the residence in Belle Terre. While fostering congernality inay be a worthy goal, ${ }^{174}$ it does not have the saine significance as getting inarried or raising children. ${ }^{175}$ Fainilial decisions are simply inucl inore important to the traditional American values of individualisin and pluralism tlian are CSO ineinbership decisions.

The question, therefore, is whether CSO's are the type of nonfamilial relationship that sliould be protected by the right of intinate association. The due process clause's concept of ordered liberty should prevent state interference witl at least soine types of voluntary association anong unrelated individuals. ${ }^{176}$ In determining whether a particular association is sufficiently intinate to inerit sucl protection, the Court has repeatedly stated that it will consider sucl factors as "size, purpose, policies, selectivity, congeniahty, and other cliaracteristics that in a particular case may be pertinent." 177 Applying these criteria, botll the Roberts and Rotary Club cases were relatively easy. ${ }^{178}$ The Jaycees were not an intimate organization because their screening of new inenibers was only cursory and their prinary purpose was professional networking. ${ }^{179}$ While the Rotary Club case was nore difficult to decide due to

173. Id. at 511 (Brennan, J., concurring).

174. See supra note 110 and accompanying text.

175. This difference is reflected in the legal obligations that accompany these respective decisions. The legal duty of spousal support often continues after the marriage has ended, as in the case of alimony or maintenance payments. Similarly, the legal duty to support one's children lasts until the children reach majority. In contrast, CSO members can terminate their legal ties to the CSO by not renewing their semester-by-semester meal and housing contracts.

176. See Board of Directors of Rotary Int'1 v. Rotary Club, 107 S. Ct. 1940, 1946 (1987) ("we have not held that constitutional protection is restricted to relationships among family members"); Moose Lodge No. 107 v. Irvis, 407 U.S. 163, 179-80 (1972) (Douglas, J., dissenting) ("The associational rights which our system honors permit all white, all black, all brown, and all yellow clubs to be formed .... Government may not tell a man or woman who his or her associates must be."); Bell v. Maryland, 378 U.S. 226, 313 (1964) (Goldberg, J., concurring) ("Prejudice and bigotry in any form are regrettable, but it is the constitutional right of every person to close his home or club to any person or to choose his social intimates and business partners solely on the basis of personal prejudice").

The extent of the right of intimate association in nonfamilial settings is an open question. At least one commentator has argued that this right should protect small groups, organized primarily for a social purpose, such as bridge clubs and, in his opinion, college fraternities and sororities. See Linder, supra note 137 , at 1886 . Other commentators have argued that this right is morc appropriately applied to cultural associations designed to preserve ethnic heritages, such as the B'Nai B'rith and the Knights of Colombus. See, e.g., Karst, Paths to Belonging: The Constitution and Cultural Identity, 56 N.C.L. REv. 303 (1986); Marshall, supra note 19, at 84-91.

177. Roberts v. United States Jaycees, 468 U.S. 609, 620 (1984); see also Rotary Club, 107 S. Ct. at 1945.

178. Both cases were decided by unanimous (7-0) votes. In Roberts, neither Chief Justice Burger nor Justice Blackmun participated in the Court's decision. In Rotary Club, Justices O'Connor and Blackmun did not participate.

179. Roberts, 468 U.S. at 612-13. 
the organization's true selectivity and long record of public service, the public nature of Rotary club events strongly indicated that club nembers were not seeking privacy from the outside world. ${ }^{180}$

As witlı the Rotary clubs, the public nature of CSO's precludes them from being protected by the right of intimate association. Singlesex CSO's are not intimate associations for the same reasons that they are not private clubs. ${ }^{181}$ They have large membership rolls (assuming alunim are mcluded), ${ }^{182}$ significant annual rates of membership turnover, ${ }^{183}$ open guest pohcies, ${ }^{184}$ sources of public funding, ${ }^{185}$ and close affiliations with institutions of higher education. ${ }^{186}$

Nevertheless, single-sex CSO's might attempt to distinguish themselves from Rotary clubs by arguing that their primary purpose is to foster congeniality. This purpose alone, liowever, is probably not sufficient to warrant constitutional protection. The friendships pronioted by CSO's generally lack the closeness and the long-term emotional commitment of truly imtimate relationships. ${ }^{187}$ Moreover, most CSO's provide their menubers with access to busmess contacts as well as social contacts. ${ }^{188}$ Hence, the many characteristics of CSO's that niake them places of pub-

180. Indeed, to promote their charitable activities, Rotary clubs generally encourage local newspaper coverage and other publicity. Rotary Club, $107 \mathrm{~S}$. Ct. at 1946-47.

Even where individuals clearly seek privacy from the outside world, however, the Court has declined to find a right of intimate association. See Bowers v. Hardwick, 106 S. Ct. 2841 (1986) (holding that consenting adults had no right to engage in homosexual conduct in the privacy of their own homes). For an analysis of the impact of the Bowers decision on an organization claiming a right of intimate association, see Marshall, supra note 19, at 81-83.

181. See Note, supra note 151, at 390-91 (arguing that organizations deemed to be public accommodations under state law cannot be private enough to be "intimate"). Compare Roberts, 468 U.S. at 620 (relevant factors in determining whether organization merits protection as intimate association are "size, purpose, policies, selectivity, congeniality") with supra text accompanying notes 92-98 (listing these same factors as criteria for determining whether arguably private entity falls under the reach of state public accommodations statute). Cf. Jones, supra note 12, at 4 (distinguishing fraternities from Jaycees and Rotary clubs on the basis of above factors, but stating that "it is hard to conclude that fraternities have the distinctive characteristics that might afford them the constitutional protection to exclude members of the opposite sex").

182. See supra text accompanying notes 116-20.

183. This turnover occurs as some CSO members graduate from the affiliated university and other students are recruited by the CSO to replace them. In the Rotary Club case, the Court indicated that such turnover weighs against a clain of intimate association. Board of Directors of Rotary Int'1 v. Rotary Club, 107 S. Ct. 1940, 1946 (1987).

184. See supra text accompanying notes 121-22.

185. See supra text accompanying notes 123-26.

186. See supra text accompanying notes 127-33.

187. See supra note 175 and accompanying text; see also Cornelius v. Benevolent Protective Order of the Elks, 382 F. Supp. 1182, 1195 (D. Conn. 1974) ("the clubhouse is of course not on the same constitutional plane as is the bedroom or study with respect to the right to privacy"); $c f$. Marshall, supra note 19, at 82 \& $\mathrm{n} .91$ (arguing that organizations such as country clubs and civic groups should not be considered intimate because "members will have only a passing acquaintancc with most of their colleagues").

188. See supra text accompanying notes 111-15. 
hic accommodation also serve to put them outside the sphere of intimate relationships meriting constitutional protection.

Even if the right of intimate association is analyzed as a "continuum" right rather than as a "threshold" right, ${ }^{189}$ it would not protect the exclusionary membership policies of single-sex CSO's. Assuming that CSO's merit soine degree of associational privacy on this continuum, their privacy interests must be balanced against the relevant state interests. Although neither the Roberts Court nor the Rotary Club Court exphcitly considered whether the right of intimate association is absolute or subject to balancing, the Court has usually applied a balancing test to define the due process clause's zone of privacy. ${ }^{190}$ Unlike cases where the state attempts to interfere with intimate family decisions, ${ }^{191}$ the state's interest in preventing gender discrimination is quite powerful. As the Roberts Court noted, states have a compelling interest in eradicating gender discrimination 192 because such discrimination "both deprives persons of their individual dignity and denies society the benefits of wide participation in political, economic, and cultural life."193

189. A "continuum right" of intimate association recognizes that all organizations possess some degree of intimacy. Under such a continuum, the degree of constitutional protection afforded to an organization varies with the degree of that organization's intimacy. For example, families receive much more protection than large business enterprises. See Roberts v. United States Jaycees, 468 U.S. 609, 620 (1984):

[A] broad range of human relationships . . . may make greater or lesser claims to constitutional protection from particular incursions by the State. Determining the limits of state authority over an individual's freedom to enter into a particular association therefore unavoidably entails a careful assessment of where that relationship's objective characteristics locate it on a spectrum from the most intimate to the most attenuated of personal attachments.

In contrast, a "threshold" right of intimate association requires an organization to show a certain level of intimacy before it can receive any constitutional protection. The preceding paragraphs of this Comment have argued that CSO's cannot make this threshold showing. See supra text accompanying notes $158-88$.

190. See, e.g., Santosky v. Kramer, 455 U.S. 745, 766-69 (1982) (clear and convincing evidence standard in child neglect proccedings balances parent's interest in raising child with state's interest in preserving child welfare); Roe v. Wade, 410 U.S. 113, 162-64 (1973) (trimester approach balances woman's choice whether to bear a child with state's interest in protecting maternal health and fetal life).

191. For discussion of the weak state interest in many of the fourteenth amendment zone of privacy cases, see Linder, supra note 137 , at $1886-87$ \& 1887 n.51.

192. Roberts, 468 U.S. at 623; see also Board of Directors of Rotary Int'l v. Rotary Club, 107 S. Ct. 1940, 1948 (1987). For a thoughtful analysis of the values underlying a state's interest in eliminating membership exclusions, see Marshall, supra note 19, at 92-99. Professor Marshall presents three reasons for prohibiting membership exclusions: a state's interest in promoting equal access to residential, educational, and business opportunities; a state's interest in not stigmatizing excluded groups; and a state's interest in redressing the wrongs suffered by historically disadvantaged groups. Professor Marshall cautions, however, that a careful weighing of these interests should not always result in finding a "compelling" state interest against exclusionary membership policies. Id. at $93,95-96$.

193. Roberts, 468 U.S. at 625 . For a discussion of the specific harms associated with the singlesex policies of CSO's, see supra notes $14-22$ and accompanying text. 
Furthermore, applying a state's public accommodations statute to single-sex CSO's promotes gender equality while infringing only slightly on intimate associational rights. By prohibiting a CSO from discriminating on the basis of gender, the state does not force it to admit any specific individual or any mdividual with whoin current members could not reasonably associate. ${ }^{194}$ Instead, state public accommodations laws simply prohibit CSO's froin using gender as a proxy for compatibility. They require CSO's to offer both sexes an equal opportunity to gain the social, recreational, and commercial benefits of meinbership. This narrow infringeinent on the limited imtimate associational rights of CSO meinbers is justified by the state's coinpelling interest in preventing sex discrimination.

In sunmary, the right of intimate association should not be interpreted to protect the inembership policies of single-sex CSO's. Unlike iınportant farnily decisions regarding marriage, childbirth, and childrearing, a CSO's choice of its inembers does not implicate values fundanuental to personal liberty. Moreover, CSO's are not intimate associations because they exhibit too many characteristics of places of public accoinmodation. These public characteristics preclude a court froin locating CSO's within the narrow constitutional spleere of intimate associations. Additionally, a state's interest in eradicating sex discrimination is a constitutionally "coinpelling interest" that justifies infringement on the ineinbership policies of CSO's.

\section{B. CSO's Are Not Expressive Associations}

The right of expressive association applies to group activities directly related to the expression of ideas protected by the first amendinent. This right does not protect all associations. It extends only to those associations that are orgamized primarily for expressive purposes, such as picket lines, ${ }^{195}$ religious organizations, ${ }^{196}$ and political coinmittees. ${ }^{197}$ CSO's do not exist to proinote the expression of ideas. While CSO's occasionally take positions on campus issues or raise funds for charity, ${ }^{198}$ their primary purpose is to proinote congeniality. ${ }^{199}$ The vast majority of a CSO's time, inoney, and effort is directed toward fostering a

194. Similarly, the Roberts Court noted that requiring the Jaycees to give equal consideration to women would not force that organization to admit members who disagreed with the Jaycees' business philosophy. See Roberts, 468 U.S. at 627.

195. NAACP v. Claiborne Hardware Co., 458 U.S. 886, 907-09 (1982).

196. Larson v. Valente, 456 U.S. 228, 255 (1982).

197. Citizens Against Rent Control v. City of Berkeley, 454 U.S. 290, 300 (1981); see also Buckley v. Valeo, 424 U.S. 1, 23, 29 (1976).

198. Such civic and charitable activities were found worthy of first amendment protection in Village of Schaumberg v. Citizens for a Better Environment, 444 U.S. 620, 632 (1980).

199. See Comment, supra note 12, at 433. 
feeling of camaraderie within the group. Given their focus on nonexpressive activity, ${ }^{200}$ single-sex CSO's possess relatively weak rights of expressive association. ${ }^{201}$

Since almost all organizations, including CSO's, engage in some degree of expressive activity, the right of expressive association must be balanced against other societal values. The Roberts Court explicitly acknowledged that an association's expressive rights can be coinpromised in order to advance an important state purpose:

The right to associate for expressive purposes is not, however, absolute. Infringements on that right may be justified by regulations adopted to serve compelling state imterests, unrelated to the suppression of ideas, that cannot be achieved through means significantly less restrictive of associational freedoms. ${ }^{202}$

The prevention of gender discrimination is the governmental motive for applying public accommodations laws to single-sex CSO's. Assuring both sexes equal access to the privileges and advantages of CSO membership almost certainly constitutes a "compelling state interest."203

Even in pursuit of such a coinpelling interest, however, a state may not suppress ideas on the basis of content. ${ }^{204}$ The application of a state public accominodations statute to single-sex CSO's does not violate this

200. Jones, supra note 12 , at 4 ("fraternities don't generally engage in ... protected activities, at least not in the way constitutional protection is normally thought to be afforded to [group expression]").

201. Under the majority test in Roberts, the strength of an organization's right to expressive association varies according to the value of that organization's first amendment activity. Roberts $v$. Umited States Jaycees, 468 U.S. 609, 628-29 (1984); see Linder, supra note 137, at 1888-89; Note, supra note 151, at 393. Since CSO's promote very little first amendment activity, the value of that activity is minimal, and their right of expressive association is weak.

The test developed by Justice O'Connor in her concurrence to the Roberts opinion would yield a similar result. Justice $O^{\prime}$ Connor advocates a threshold approach with two different degrees of constitutional protection. If an association is "predominantly engaged in protected expression," the state cannot regulate its membership so as to affect its "collective voice." Roberts, 468 U.S. at 635-36 (O'Connor, J., concurring). If, however, the association's activities are primarily commercial or otherwise nonexpressive, a state must pass only the "rational relation" test to regulate the association's meinbership. Id.; see also Linder, supra note 137, at 1894-95; Note, supra note 151, at 388-89 \& n.139. Although CSO's are not primarily commercial, their degree of expressive activity is less than that of the Jaycees. See Linder, supra note 137, at $1895 \mathrm{n} .92$; see also infra note 207. Since Justice $O^{\prime}$ Connor did not find the Jaycees to be a predominantly expressive association, she presumably would find that CSO's are not predominantly expressive either. Hence, under her test, states probably could regulate the membership policies of CSO's merely by showing that such regulation is "rationally related" to the prevention of gender discrimination. But see Roberts, 468 U.S. at 636 (O'Connor, J., concurring) (indicating that Boy Scouts and Girl Scouts may be predominantly expressive organizations).

202. Roberts, 468 U.S. at 623; see also Board of Directors of Rotary Int'l v. Rotary Club, 107 S. Ct. 1940, 1947-48 (1987).

203. See supra notes $192-93$ and accompanying text; see also New York State Club Ass'n v. City of New York, 69 N.Y.2d 211, 505 N.E.2d 915, 513 N.Y.S.2d 349, prob. juris. noted, 108 S. Ct. 62 (1987).

204. Rotary Club, 107 S. Ct. at 1947-48; Roberts, 468 U.S. at 623. 
first amendment constraint. While single-sex CSO's may have slightly different concerns and may voice slightly different messages than integrated CSO's, the judicially mandated imtegration of CSO's does not suppress the single-sex message on the basis of content. Public accommodations statutes regulate the composition of a group, not the content of the group's message. ${ }^{205}$ After integrating, CSO's and their individual members reinam free to express themselves as they see fit. An integrated CSO can maintain the same substantive views and positions as its single-sex predecessor, or it can change its inessage in accordance with its newly integrated membership's wishes.

To apply its public accommodations law to CSO's, a state inust also show that no less intrusive ineans is available to promote gender equality. ${ }^{206}$ Requiring CSO's to give equal consideration to individuals regardless of gender satisfies this requirement. Public accommodations statutes do not force CSO's to admit all individuals of the formerly excluded gender who seek membership. Instead, CSO's simply inust give all applicants equal consideration. This approach allows CSO's to maintain their congenial atmosphere by selecting individuals whom their inenibers find conipatible. This approach also suggests that integration probably would not have a noticeable impact on the expressive activity of inost CSO's.

Overall, CSO's have a weaker claim to the right of expressive association than did the Jaycees and the Rotary clubs. Jaycees and Rotary clubs engage in more expressive activity than CSO's, ${ }^{207}$ and the state interest in integrating CSO's is no less compelling than the state interest at stake in Roberts and Rotary Club. Since the Supreme Court ruled that the right of expressive association did not protect the single-sex membership policies of the Jaycees and the Rotary clubs, this right should not protect the membership policies of single-sex CSO's either. ${ }^{208}$

205. These statutes are simply another example of the state's power to regulate the method of expression where such regulation is not related to the substantive content of the expression. For example, states have the power to enact noise ordinances as long as those ordinances are based on decibel levels and not on the content of the alleged "noise." See, e.g., Kovacs v. Cooper, 336 U.S. 77, 87 (1949) (upholding ordinance that prohibited sound trucks from broadcasting any messages "amplified to a loud and raucous volume").

206. Rotary Club, 107 S. Ct. at 1947-48; Roberts, 468 U.S. at 623.

207. The Jaycees have passed resolutions and taken public stances on many issues, including school prayer, the Panama Canal Treaty, and the Vietnam War. United States Jaycees v. McClure, 709 F.2d 1560, 1569-70 (8th Cir. 1983), rev'd, 468 U.S. 609, 626 (1984) (noting that "[o]ver the years, the national and local levels of the [Jaycee] organization have taken public positions on a number of diverse issues"). While Rotary clubs do not take positions on public issues, they do participate in a siguificant amount of charitable fundraising that is considered expressive activity under the first amendment. Rotary Club, $107 \mathrm{~S}$. Ct. at 1947. In contrast, CSO's spend the majority of their time fostering a congenial social environment. See Comment, supra note 12, at 433.

208. Even a supporter of single-sex CSO's concedes that a state's interest in promoting gender equality should outweigh a CSO's claim to expressive associational rights. Comment, supra note 12, 
In summary, neither the constitutional right of intimate association nor the constitutional right of expressive association should protect the membership policies of single-sex CSO's. If a plaintiff can establish under the relevant state statute that a CSO is a place of public accomınodation, he should prevail in challenging the CSO's single-sex policies.

\section{IV \\ Constitutional Equal Protection Challenge}

Some states have not passed public accommodations laws broad enough to serve as grounds for attacking CSO membership policies. ${ }^{209}$ In such states, a plaintiff might attempt a challenge based on the equal protection clause of the fourteenth amendment. Although CSO's have existed for more than two centuries, ${ }^{210}$ recent decisions of the Uinted States Supreme Court suggest a judicial willingness to reevaluate the constitutionality of long-standing gender classifications. ${ }^{211}$

Such a constitutional attack faces two distinct hurdles. First, the fourteenth amendment declares that "No State shall . . . deny to any person within its jurisdiction the equal protection of the laws." 212 The Supreme Court has consistently interpreted this language to mean that the amendment "applies to acts of the states, not to acts of private persons or entities." 213 Consequently, the threshold requirement for an equal protection challenge is showing that the membership policies of a CSO constitute "state action."

The second hurdle is establishing that the single-sex policies of CSO's fail the "intermediate scrutiny" test that the Court currently

at 433; see also Runyon v. McCrary, 427 U.S. 160, 176 (1976) (refusing to constitutionally protect the practice of excluding racial mmorities from certain educational institutions: "while "ii]nvidious privatc discrimination may be characterized as a form of exercising freedom of association protected by the First Amendment ... it has never been accorded affirmative constitutional protections' ") (quoting Norwood v. Harrison, 413 U.S. 455, 470 (1973)); Note, Section 1981 and the Thirteenth Amendment after Runyon v. McCrary-On the Doorstep of Discriminatory Private Clubs, 29 STAN. L. REV. 747, 758-70 (1977) (arguing that Runyon makes constitutional defenses unavailable to discriminatory private clubs).

209. Not all states have enacted public accommodations legislation, and a few of the states that have enacted such legislation do not define gender as a prohibited form of discrimination. See supra text accompanying notes 41-42. In addition, courts in states with the appropriate legislation may hold that CSO's are not places of public accommodation. See supra note 128.

210. W. Musgrave, College Fraternities 6 (1923).

211. See Mississippi Univ. for Women v. Hogan, 458 U.S. 718 (1982) (holding unconstitutional a century-old Mississippi statute that prohibited males from enrolling in state-supported nursing school); Craig v. Boren, 429 U.S. 190 (1976) (holding unconstitutional a long-standing Oklahoma statute that prohibited the sale of "near beer" to males under the age of 21 and females under the age of 18); $c f$. Board of Directors of Rotary Int'1 v. Rotary Club, 107 S. Ct. 1940 (1987) (upholding a California statute that requires California Rotary clubs to admit women as members).

212. U.S. CONST. amend. XIV, $\S 1$.

213. Rendell-Baker v. Kohn, 457 U.S. 830, 837 (1982); see also Lugar v. Edmondson Oil Co., 457 U.S. 922, 936-37 (1982). 
applies to gender classifications. The Court has ruled that "classifications by gender must serve important governmental objectives and must be substantially related to [the] achievement of those objectives."214 While this test is not as strict as the "compelling state interest" test that the Court applies to racial classifications, it is much stricter than the "rational basis" test that the Court applies to economic regulations and nonsuspect classifications. ${ }^{215}$

Part IV of this Comment discusses the circumstances im which a litigant can clear these two hurdles and invoke the equal protection clause against a smgle-sex CSO. Section A analyzes the relationship of CSO's to the state and determines that this relationship satisfies the requirement of state action only im the case of public umiversities. Section $B$ then apphies the intermediate scrutiny test to the inembership policies of single-sex CSO's at public universities. It evaluates the reasons typically asserted in support of single-sex CSO's and finds that none satisfies the "important governmental objective" test set forth by the Supreme Court. Hence, this Comment concludes that CSO's at public universities cannot constitutionally maintain single-sex membership policies.

\section{A. State Action Analysis}

The concept of state action is ratler hazy. Government is involved im so many aspects of modern American society that distimguislimg between state action and private action is often difficult. Nevertheless, federal courts must regularly decide whether the actions of a school board, student association, or other education-related organization constitute state action. ${ }^{216}$ In determining whether a CSO's membership pohcies constitute state action, a court must analyze the relationship between the CSO and the state. The key to understanding this relationship is the umiversity, which stands between the CSO and the state. Where the umversity is an extension of the state, rather than an imdependent entity, the CSO's affiliated with that university should also be considered state

214. Boren, 429 U.S. at 197; see also Kirchberg v. Feenstra, 450 U.S. 455,461 (1981); Personnel Adm'r v. Feeney, 442 U.S. 256, 273 (1979).

215. See Seeburger, The Muddle of the Middle Tier: The Coming Crisis in Equal Protection, 48 Mo. L. REv. 587, 607-14 (1983); Wildman, supra note 22, at 276, 286; see also infra note 256 and accompanying text.

216. See, e.g., Arlosoroff v. NCAA, 746 F.2d 1019, 1022 (4th Cir. 1984) (defendant's eligibility rule does not constitute state action despite prevalence of public institutions in NCAA); Hennessey v. NCAA, 564 F.2d 1136, 1144 (Sth Cir. 1977) (NCAA's bylaws constitute state action); Hart v. Cominunity School Bd. of Educ., 512 F.2d 37, 51 (2d Cir. 1975) (local school board is state actor); Gay \& Lesbian Students Ass'n v. Gohn, 656 F. Supp. 1045, 1051-53 (W.D. Ark. 1987) (student government's denial of funding to plaintiff association constitutes state action); Johnson v. Educational Testing Serv., Inc., 615 F. Supp. 633, 635-36 (D. Mass. 1984) (corporation that administers law school admission test not a state actor), aff'd, 754 F.2d 20 (1st Cir.), cert. denied, 472 U.S. 1029 (1985). 
actors. The rationale behind this argument is that where a state controls a umiversity, and that university controls its CSO's, the state should be held accountable for those CSO's. ${ }^{217}$

The first step nit this analysis requires a determination of whether the umiversity in question should be considered a state actor. To determine the presence or absence of state action, the Supreme Court has developed a number of different tests rather than consistently applying a single test. $^{218}$ The Court also has apphed more than one test to a given fact situation, suggesting that these tests are not mutually exclusive. ${ }^{219} \mathrm{Con}$ sequently, lower federal courts tend to find state action where the challenged conduct satisfies any one of the Supreme Court's tests. ${ }^{220}$

The most appropriate test for analyzing the relationship between the state and an educational imstitution is the "symbiotic relationship" test. $^{221}$ The Supreme Court first developed this test in Burton v. Wil-

217. The theory underlying this argument is that where a state establishes an institution, it should be responsible for those organizations integrally connected with that institution. For example, since police departments are state actors, organizations operating under the aegis of police departments, such as police benevolent associations, also should be considered state actors. See Adams v. Miami Police Benevolent Ass'n, Inc., 454 F.2d 1315, 1317-18 (5th Cir.) (holding that defendant's racially discriminatory policies constituted state action because the defendant "was so closely entwined with the City of Miami Police Department"), cert. denied, 409 U.S. 843 (1972).

218. See Lugar v. Edmondson Oil Co., 457 U.S. 922, 939 (1982) (noting that the Court lias developed at least four different tests: the "symbiotic relationship" test, the "nexus" test, the "public fnnction" test, and the "state compulsion" test); see also Goodwin, supra note 113, at 246-51 (briefly describing these various tests).

219. See Lugar, 457 U.S. at 939 ("Whether these different tests are actually different in operation or simply different ways of characterizing the necessarily fact-bound inquiry ... need not be resolved here."); Rendell-Baker v. Kolın, 457 U.S. 830, 840-43 (1982) (applying three of the different tests listed in Lugar).

220. See, e.g., Krynicky v. University of Pittsburgh, 742 F.2d 94, 99-101 (3d Cir. 1984) (holding that the nexus test has not replaced the symbiotic relationship test), cert. denied, 471 U.S. 1015 (1985); Newsom v. Vanderbilt Univ., 653 F.2d 1100, 1113-16 (6th Cir. 1981) (applying multiplc tests); Benner v. Oswald, 444 F. Supp. 545, 556 (M.D. Pa. 1978) ("If [a symbiotic relationship] is found to exist, all of the entity's actions are state actions and a nexus between any state regulation and the action need not be shown."), aff'd, 592 F.2d 174 (3d Cir.), cert. denied, 444 U.S. 832 (1979).

221. Many courts have used this test in determining whether the conduct of a university constituted state action. See, e.g., Molthan v. Teinple Univ., 778 F.2d 955, 960-61 (3d Cir. 1985) (defendant university is state actor under syıbiotic relationship test of Krynicky); Martin v. Delaware Law School, 625 F. Supp. 1288, 1301 (D. Del. 1985) (plaintiff failed to show syinbiotic relationship between state and defendant institution); Sinith v. Duquesne Univ., 612 F. Supp. 72, 7778 (W.D. Pa. 1985) (same), aff'd, 787 F.2d 583 (3d Cir. 1986).

Most courts apply this test, however, as a secondary step in deciding the state action issue. The first stage of analysis is usually the nexus test. See, e.g., Rendell-Baker, 457 U.S. at 839.43 (petitioner did not establish state action under either nexus test or syinbiotic relationship test); Krynicky, 742 F.2d at $99-101$ (noting that symbiotic relationship test is analytically distinct froın nexus test).

The nexus test examines the contacts among the state, the institution, and the conduct at issuc to determine whether the state compelled or required this conduct. See Jackson v. Metropolitan Edison Co., 419 U.S. 345, 351 (1974) (termination of electric service by utility company not state action); Moose Lodge No. 107 v. Irvis, 407 U.S. 163, 176 (1972) (liquor licensing "does not sufficiently implicate the state" in club's meinbership policies to make club's refusal to serve blacks 
mington Parking Authority. ${ }^{222}$ The issue in Burton was whether a private coffee shop, located in a parking facility that was owned, operated, and inaintained by the state of Delaware, could refuse to serve blacks. In holding that the fourteenth annendinent prohibited such discrimination, the Court found state action on the basis of the state's inutually beneficial leasehold with the coffee shop. ${ }^{223}$ The Court reasoned that by owning the land and structure that housed the coffee shop and by receiving rental payments froin the coffee shop, the state had "so far insinuated itself into a position of interdependence with [the coffee shop] that it must be recognized as a joint participant in the challenged activity."224

The Supreme Court has not yet defined the symbiotic relationship test more precisely than this "joint participant" standard. Nevertheless, a comparison of recent cases involving educational institutions helps illuminate the factors that most federal courts consider indicative of a symbiotic relationship. Rendell-Baker $v$. Kohn ${ }^{225}$ was an action against a high school for maladjusted students brought by former teachers who claimed to have been discharged in violation of their constitutional due process rights. ${ }^{226}$ The teachers argued that since Massachusetts financially subsidized and extensively regulated high schools for maladjusted students, their former employer was a state actor. The Supreme Court, however, held that these factors alone were insufficient to estabhish a symbiotic relationship between the state and the high school in question. $^{227}$

state action). See generally Buchanan, Challenging State Acts of Authorization under the Fourteenth Amendment, 57 WASH. L. REv. 245 (1982).

Under the nexus test, a plaintiff challenging the membership policies of a single-sex CSO probably cannot establish state action. No state compels or requires CSO's to restrict their membership to one sex.

Hence, this Comment focuses on the second stage of analysis, the symbiotic relationslip test. Whereas the nexus test evaluates contacts one-by-one and ascertains the state's impact on the cliallenged conduct, the symbiotic relationship test looks at the cumulative effect of the state's involvement witl tlie challenged entity. It empliasizes the overall relationship between the state and the claallenged entity ratler than the specific relationship between the state and the challenged conduct. Many commentators liave argued that the symbiotic relationship test is better because of its broader focus. This broader focus enables the test to analyze the big picture and determine whetler the state slould be responsible for the cliallenged institution. In contrast, due to its seriatim approach, the nexus test often focuses on individual trees and fails to discern the surrounding forest. See Burns, supra note 14, at 347; Goodwin, supra note 218, at 248-50; $f$. Rhode, supra note 7, at 126.

222. 365 U.S. 715 (1961).

223. Id. at 723-24.

224. Id. at 725 .

225. 457 U.S. 830 (1982).

226. Although the suit was brought under 42 U.S.C. $\S 1983$, the Supreme Court lias held that the state action requirement for such suits is the same as under the fourteentli amendment. Id. at 838 (citing United States v. Price, 383 U.S. 787, 794 n.7 (1966)).

227. Rendell-Baker, 457 U.S. at 842-43. The Rendell-Baker Court also lield that the plaintiffs failed to show state action under the nexus test. Id. at 840-41. 
In contrast, in Krynicky v. University of Pittsburgh, ${ }^{228}$ the Third Circuit held that the umversity's denial of tenure to a faculty member was state action. The Court found a symbiotic relationship between the University of Pittsburgh and the Commonwealth of Pennsylvania on the basis of the "Umiversity of Pittsburgh-Commonwealth Act."229 This Act describes the University of Pittsburgh as an "instrumentality" of Pennsylvania and sets forth a series of specific linkages between the university and the state. ${ }^{230}$ The Third Circuit noted that, under the Act, the state appoints one-third of the university's trustees, makes annual appropriations for specified uses, and oversees the umiversity's budget. ${ }^{231}$

The rationale for finding a symbiotic relationship in Krynicky, but not in Rendell-Baker, is the specificity and the extent of the relevant state statutes. While the school in Rendell-Baker was regulated and funded through state statutes, these statutes apphed to all high schools for maladjusted students. The statute in Krynicky, however, apphied specifically to the Umiversity of Pittsburgh. The Third Circuit based its finding of a symbiotic relationship on this "affirmative state act of statutorily accepting responsibility,"232 enuphasizing that the statute provided significant linkages between the umversity and the state. Under the terminology of Burton, the extent of these linkages made Pennsylvania a "joint participant" in the university's educational venture.

The reasoning of Krynicky is applicable to many colleges and universities. Several states have enacted legislation that establishes, funds, and regulates specific institutions of higher education. ${ }^{233}$ While courts must evaluate the depth of a state's involvement with an educational institution on an individual basis, ${ }^{234}$ they have generally found that such "pubhc" universities are state actors. ${ }^{235}$ In contrast, the majority of

228. 742 F.2d 94 (3d Cir. 1984), cert. denied, 471 U.S. 1015 (1985).

229. Id. at 101-02.

230. Pa. Stat. ANn. tit. 24, $\S \S 2510-202$ to $2510-210$ (Purdon 1966).

231. Krynicky, 742 F.2d at 102.

232. Id.

233. See, e.g., ARK. Stat. ANN. $\S 80-2812$ (1980); CAL. Educ. Code $\S 92000$ (West 1978); PA. STAT. ANN. tit. 24, $\$ \S 2510-1$ to 2510-11, 2510-201 to 2510-211; WASH. REV. CODE ANN. $\$ 28 B .50$ (1982).

234. Cf. Burton v. Wilmington Parking Auth., 365 U.S. 715, 722 (1961) ("Only by sifting facts and weighing circumstances can the nonobvious involvement of the State in private conduct be attributed its true significance.").

235. See, e.g., Molthan v. Temple Univ., 788 F.2d 955, 960-61 (3d Cir. 1985) (university is state actor due to its statutory relationship with state); Brown v. Strickler, 422 F.2d 1000, 1001 (6th Cir. 1970) (actions by statutorily defined "municipal university" constitute state action); Hammond v. University of Tampa, 344 F.2d 951, 951 (5th Cir. 1965) (defendant is state actor because "its establishment was largely made possible by the use of a surplus city building and the use of other city land leased for the University purposes"); see also Thigpen, The Application of Fourteenth Amendment Norms to Private Colleges and Universities, 11 J. L. \& EDuc. 171, 201 (1982) ("state financing and control ... brought public colleges within reach of the fourteenth amendment") (footnote omitted); cf. Wynne v. Shippensburg Univ., 639 F. Supp. 76, $79-80$ (M.D. Pa. 1985) 
American colleges and universities are "private" in the sense that they are not the subject of a specific state statute. Although these private schools perform the public function of education and often receive financial support from the state, ${ }^{236}$ courts have repeatedly held that these two factors alone do not constitute a symbiotic relationship. ${ }^{237}$ Thus, for the purpose of analyzing equal protection claims under the fourteenth amendnient, the prevailing legal norm is that public colleges and universities are state actors while private institutions are not. ${ }^{238}$

Since niany public universities are state actors, the next step in establishing an equal protection violation is to determine whether such universities are responsible for the membership policies of their CSO's. Analytically, this issue is quite similar to determining whether a university is a state actor. The question is whether the public university, as part of the state, has a symbiotic relationship with its CSO's. In other words, has the state, through its university, "so far insmuated itself into a position of interdependence" with the CSO's "that it inust be recognized as a joint participant" in their exclusionary policies? ${ }^{239}$ Though no court has addressed this question directly, ${ }^{240}$ cases involving other types of student

(applying sovereign immumity to public university on the ground that it is "arm" or "alter ego" of state); Carlson v. Highter, 612 F. Supp. 603, 604 (E.D. Tenn. 1985) (same).

236. This financial support takes many forms, including direct loans and grants to the school, loans and grants to students attending the school, and various tax exemptions.

237. See, e.g., Martin v. Delaware Law School, 625 F. Supp. 1288, 1301 (D. Del. 1985) (extensive state regulation and state-granted charter do not show "pervasive interdependence" necessary to constitute symbiotic relationship); Smith v. Duquesne Univ., 612 F. Supp. 72, 77-78 (W.D. Pa. 1985) (finding no state action since the state had never statutorily accepted responsibility for the defendant university), aff'd, 787 F.2d 583 (3d Cir. 1986); Cohen v. President \& Fellows of Harvard College, 568 F. Supp. 658, 661 (D. Mass. 1983) (no symbiotic relationship because decisions of defendant college "unconnected" with any state financing), aff'd, 729 F.2d 59 (1st Cir.), cert. denied, 469 U.S. 874 (1984). See generally Thigpen, supra note 235, at 195-201, 201 ("Despite increased involvement by government in affairs of private colleges and umiversities, however, they remain technically immune from the restrictions of the fourtecnth amendinent."); Annotation, 37 A.L.R. FED. 601 (1978) (discussing major theories of state action and describing cases applying these theories to both public and private umiversities).

238. Cf. Powe v. Miles, 407 F.2d 73 (2d Cir. 1968) (opinion by Friendly, J.). In Powe, several students from Alfred University's Liberal Arts College and Ceranic Arts College sought reinstatement on the ground that their suspensions for engaging in an allegedly disruptive demonstration violated their first amendment rights. While the court found no state action in the suspension of the liberal arts students, it held that the suspension of the ceramics students for the same incident did constitute state action. The court based this distimction on the fact that New York statutes treated the Ceramics Arts College as "an integral part of the State University" and provided $100 \%$ of its funding. Id. at 82 .

239. This symbiotic relationship test paraphrases Burton v. Wilmington Parking Auth., 365 U.S. 715,725 (1961). It has been applied in at lcast one case involving the conduct of a student organization at a public college. See Sellman v. Baruch College, 482 F. Supp. 475, 478-79 (S.D.N.Y. 1979) (student government is state actor due to its "interlocking relationship" with public college).

240. Cases in which a plaintiff has sought to hold a university liable for conduct occurring at a CSO have generally involved tort claims. See University of Denver v. Whitlock, 744 P.2d 54, $61-62$ (Colo. 1987) (university not liable for injuries sustained by fraternity member who was jumping on a trampoline during fraternity party); Campbell v. Board of Trustees, 495 N.E.2d 227, 233 (Ind. Ct. 
organizations provide useful analogies. For example, courts have found state action in the conduct of both student governments ${ }^{241}$ and student newspapers ${ }^{242}$ at public universities.

Courts have focused on numerous factors in deciding whether a student organization at a public umversity is a state actor. They generally examine the degree to which the public university aids, regulates, and benefits from the student organization at issue. Hence, courts ask whether the university created or approved the organization, whether it funds the organization, whether it allows the organization to use campus facilities, and whether it advises or supervises the organization. ${ }^{243}$ While none of these factors is determmative in and of itself, the presence of all or most of them usually persuades a court that the public university and the challenged organization are symbiotic partners. ${ }^{244}$

The prevalence of these factors in the relationships between public universities and their CSO's demonstrates that such CSO's should be considered state actors. While public universities do not create CSO's, they do approve them, often through written sponsorship agreements. Under these agreenients, CSO's promise to conform to certain university policies and, in exchange, the university recognizes the CSO's as "sponsored" organizations. ${ }^{245}$ Fron the university's standpoint, these agreements serve as a means of regulating the conduct and policies of CSO's. This regulation extends to menibership policies because sponsorship

App. 1986) (college not liable for damages resulting from car accident caused by driver who became imtoxicated at fraternity party). The issue in such cases is whether the university acted negligently in failing to prevent individual CSO members from harming themselves or others.

In contrast, the issue that concerns this Comment is whether public universities are responsible for the membership policies of their CSO's. Of course, tests of legal responsibility for state action are quite different from legal standards of tort negligence.

241. Gay \& Lesbian Students Ass'n v. Gohn, 656 F. Supp. 1045, 1053 (W.D. Ark. 1987) (student government's denial of funding to plaintiff association constituted state aetion); Sellman, 482 F. Supp. at $478-79$ (city college's election procedures for student government constituted state action).

242. Kania v. Fordham, 702 F.2d 475 (4th Cir. 1983) (requiring student fees to fund newspaper at University of North Carolina constituted state action); Lee v. Board of Regents, 441 F.2d 1257, 1260 (7th Cir. 1971) (holding that "the [defendant] board's undoubted power over the administration of the state universities" made it proper party in constitutional attack against editorial policies of public university's newspaper); $c f$. Sinn v. Daily Nebraskan, 638 F. Supp. 143, 148 (D. Neb. 1986) (student newspaper "functions as a private newspaper for some purposes, but as an agency of the state in all other respects"), aff'd, 829 F.2d 662 (8th Cir. 1987).

243. See Gay \& Lesbian Students Ass'n, 656 F. Supp. at 1053; Sellman, 482 F. Supp. at 478.

244. See, e.g., Sellman, 482 F. Supp. at 478-79:

[B]oth the College and the students derive benefit from this interlocking relationship. Although none of these factors [showing the interlocking relationship], standing alone, would constitute the requisite degree of state involvement, in combination, they do. ... The state is sufficiently involved in the governance and control of Baruch College that the action of its student government may be attributed to the state itself.

(footnote omitted).

245. See, e.g., UC-Berkeley Sponsorship Agreement, supra note 131; St. LAWrence UNIV. RECIPROCAL AGREEMENT, supra note 131. 
agreements often prohibit CSO's from discriminatimg "on the basis of race, religion, or national origin."246 In return, CSO's receive many benefits from their sponsored status, including office space on campus, access to mailing lists of new students, and the right to apply for umiversity funds. Much like the lease in Burton and the statute in Krynicky, sponsorship agreements illustrate the symbiotic nature of the relationships between public universities and their CSO's.

Even in the absence of a formal sponsorship agreement, other factors may establish an interdependent relationship between a public university and its CSO's. For example, many public umversities lease state land and buildings to CSO's for use as houses. ${ }^{247}$ Aside front this direct funding, some universities indirectly fund their CSO's by providing financial aid to students who otherwise would not be able to afford CSO membership. ${ }^{248}$ In addition, umiversities often hire special advisors to supervise the affairs of CSO's and to act as the university's liaison to them. ${ }^{249}$ Umiversities help their CSO's in these ways because CSO's benefit umversities by feeding and housmg a substantial percentage of the student body, ${ }^{250}$ by helping to attract new students to the umversity, ${ }^{251}$ and by helping to persuade former students to contribute money. ${ }^{252}$

Given these factors, a plaimtiff should be able to show a symbiotic relationship between a public university and its CSO's. Since public universities are part of the state, their symbiotic relationship with their CSO's makes these CSO's state actors. Having thus met the "state action" requirement of an equal protection challenge, a plaintiff is situ-

246. UC-BERKELEY SPONSORSHIP AGREEMENT, supra note 131.

247. To determine whether a particular university leases land and buildings to its CSO's, see Baird's MANUAL OF AMERICAN Colleges AND Fraternities (19th ed. 1977) (briefly describing the status of CSO's at almost every American four-year institution of higher education).

For court decisions finding state action in the conduct of an entity that leased state land, see Burton v. Wilmington Parking Auth., 365 U.S. 715 (1961) (described supra in text acconpanying notes 222-24); Citizens Council on Human Relations v. Buffalo Yacht Club, 438 F. Supp. 316 (W.D.N.Y. 1977) (holding that state action may be present where defendant club leased state land for one dollar and received state liquor license). But see Golden v. Biscayne Bay Yacht Club, 530 F.2d 16, 22 (5th Cir. 1976) (lease between yacht club and City of Miami did not make the city "a joint participant in the internal membership policies of the club").

248. See supra note 123 and accompanying text.

249. Interview with Mr. William Wrightsman, fraternity advisor at the Umiversity of California at Berkeley.

250. For example, at both the University of California at Berkeley, and the University of Illinois at Urbana-Champaign, approximately $17 \%$ of the undergraduate population belongs to CSO's. J. CAss \& M. BirnBaum, sup:a note 16, at 70, 211. Many umiversities would experience difficulty and expense if they had to meet the housing and food needs of their students without the aid of CSO's. See, e.g., Frank v. Ivy Club, Nos. PL 05-1678, 05-1679, 05-1680, at $42-43$ (N.J. Dep't of Law \& Public Safety, Div. on Civil Rights, Finding of Probablc Cause, Feb. 6, 1986).

251. Universities capitalize on the promotional value of CSO's by describing these organizations in brochures and catalogs sent to prospeetive students.

252. Studies have indicated that a greater percentage of fraternity alumni contribute money to their alma mater than do nonfraternity alumni. See Rumsey, supra note 34, at 466 \& n.9. 
ated to argue that the equal protection clause prohibits such CSO's from choosing members on the basis of gender.

\section{B. The Intermediate Scrutiny Test}

Over the past two decades, the United States Supreme Court has closely examined the issue of gender classifications. ${ }^{253}$ Much of the judicial debate in this area has focused on the standard of review to be apphied to such classifications. ${ }^{254}$ Although many commentators have argued that classifying an mdividual on the basis of gender is as pernicious as classifications based on race, ${ }^{255}$ the Court has declined to label gender a "suspect classification" requiring strict judicial scrutiny. ${ }^{256}$ Nevertheless, the Court has recognized that "our Nation has had a long and unfortunate history of sex discrimination."257 Hence, rather than completely deferring to state action involving gender classifications, the Court has developed an intermediate standard of review. ${ }^{258}$ To survive an equal protection challenge under this standard, "classifications by gender must serve important governmental objectives and must be substantially related to [the] achievement of those objectives."259

The Court has applied this intermediate test rather systematically. Once a plaintiff establislies that the state actor has classified individuals on the basis of gender, tlie burden falls on the state actor to show an "exceedingly persuasive justification" for that classification. ${ }^{260}$ The state actor can only meet this burden by satisfymg botli prongs of the intermediate scrutimy test. First, the state actor must demonstrate that the challenged classification serves an "important governmental objective." The Court has indicated that it will not blindly accept the state actor's asserted objectives. ${ }^{261}$ Instead, the Court will scrutinize these objectives

253. Between 1970 and 1985, the Court issued decisions in at least 31 cases involving allegations of gender discrimination. For a comprehensive list of these cases, see Kay, supra note 22, at 67.68 nn. $200-01$.

254. See, e.g., Frontiero v. Richardson, 411 U.S. 677, 688, 691-92 (1973) (disputc between plurality and concurrence regarding level of judicial scrutiny appropriate for gender classifications).

255. See Karst, supra note 20, at 22-23; Kay, supra note 22, at $65-66$; Wildman, supra note 22, at 276, 286-87.

256. Craig v. Boren, 429 U.S. 190, $197-99$ (1976); see also sources cited supra note 255.

To survive strict judicial scrutiny, a classification must serve a "compelling state interest" and be narrowly tailored to serve that interest. See Dunn v. Blumstein, 405 U.S. 330, 342 (1972); Loving v. Virginia, 388 U.S. 1, 11 (1967). See generally L. TR1BE, AMERICAN CONSTITUTIONAL LAW 1000-57 (1978) (discussing classifications to which the Court has applied strict scrutiny).

257. Frontiero, 411 U.S. at 684.

258. See supra text accompanying note 215.

259. Boren, 429 U.S. at 197; see also Mississippi Univ. for Women v. Hogan, 458 U.S. 718, 724 (1982) (setting forth identical standard); Califano v. Webster, 430 U.S. 313, 316-17 (1977) (quoting Boren).

260. Mississippi Univ. for Women, 458 U.S. at 724; Kirchberg v. Feenstra, 450 U.S. 455, 461 (1981); Personnel Adm'r v. Feeney, 442 U.S. 256, 273 (1979).

261. Mississippi Univ. for Women, 458 U.S. at 725 ("[c]are must be taken in ascertaining 
to determine both their legitimacy and importance. Even if an asserted objective is arguably important, it will not survive intermediate scrutiny if it "reflects archaic and stereotypic notions" or "fixed notions concerning the roles and abilities of males and females."262

Second, assuming that the state actor has established a valid and important objective, it inust also show that its gender classification is "substantially related" to achieving that objective. This prong requires a close and direct link between the gender classification and the important governmental objective. ${ }^{263}$ Hence, the Court will strike down state action that "employ[s] gender as an inaccurate proxy for other, inore germane bases of classification." 264

Two significant cases in whicl the Court has applied the intermediate scrutiny test are Mississippi University for Women v. Hogan ${ }^{265}$ and Craig v. Boren. ${ }^{266}$ In both cases, the Court ruled that since the state actor had failed to demonstrate a persuasive justification, the challenged gender classification was unconstitutional. A brief description of these cases illustrates the Court's application of its two-prong test and suggests that the inembership policies of single-sex CSO's are vulnerable under this test.

In Mississippi University for Women, the Court struck down a Mississippi statute that excluded males froin enrolling in the University's School of Nursing. Mississippi sponsored two other public nursing schools open to inen and argued that its maintenance of the all-female program at issue simply provided female nursing students with an additional educational choice. ${ }^{267}$ Thus, Mississippi argued that the cliallenged program constituted "educational affirmative action" for women. ${ }^{268}$ The Court held that this affirmative action claim failed the first prong of the intermediate scrutiny test on the dual grounds that it was unsupported and that its objective was impermissible. Mississippi's asserted objective was unsupported by the evidence because the state

whether the statutory objective itself ... is illegitimate"); see also Heckler v. Mathews, 465 U.S. 728, 744 (1984) (quoting Mississippi Univ. for Women approvingly); cf. Boren, 429 U.S. at 199 n.7 ("leaving for another day consideration of whether ... the Court [should] determine if the litigant simply is selecting a convenient, but false, post hoc rationalization") (italics in original).

262. Mississippi Univ. for Women, 458 U.S. at 725 (quoted approvingly in Heckler, 465 U.S. at 744).

263. Heckler, 465 U.S. at 745 (state actor has burden of "demonstrating 'the requisite direct, substantial relationship' between the classification and the important governmental objectives it purports to serve") (quoting Mississippi Univ. for Women, 458 U.S. at 725).

264. Boren, 429 U.S. at 198 (quoted approvingly in Mississippi Univ. for Women, 458 U.S. at 726).

265. 458 U.S. 718 (1982).

266. 429 U.S. 190 (1976).

267. Mississippi Univ. for Women, 458 U.S. at 734 (Blackmun, J., dissenting), 743-44 \& n.12 (Powell, J., dissenting).

268. Id. at 727. 
"failed to estabhish that the legislature intended the single-sex policy to compensate for any perceived discrimination."269 Moreover, the Court ruled that this putative objective was invalid. Since women already enjoyed greater opportumities and more representation in the nursing profession than men, the Court saw no reason to grant women an educational advantage in this profession. It concluded that Mississippi's affirmative action goal was an impermissible governmental objective as applied to nursing sclools: "Rather than compensat[ing] for discriminatory barriers faced by women, MUW's policy of excluding males . . . tends to perpetuate the stereotyped view of nursing as an exclusively woman's job."270

Craig v. Boren illustrates the second prong of the intermediate scrutimy test. It involved an Oklalioina law prohibiting the sale of "low alcohol" beer to males under age twenty-one, but permitting its sale to feinales eighteen or older. Oklahoma argued that this statute served the important state interest of traffic safety. ${ }^{271}$ In support of this argument, Oklahoma demonstrated that 18-to-20-year-old males were much more frequently arrested for driving under the influence than females in the same age group. ${ }^{272}$ However, the Court found that such statistics did not establisl a substantial correlation between gender and drunken driving because only $0.18 \%$ of all females and $2 \%$ of all males in the relevant age group had actually been arrested for sucl offenses. ${ }^{273}$ In holding the Oklalioma statute unconstitutional, the Court reasoned that sucl a small correlation did not satisfy the "substantially related" prong of the intermediate scrutiny test. ${ }^{274}$

Plaintiffs challenging the membership policies of single-sex CSO's at public universities can rely on these two cases. Assuming the thresliold requirement of state action is met, ${ }^{275}$ plaintiffs can shift the burden of proof to the challenged CSO's by establishing that these CSO's based their memberslip selections on gender. ${ }^{276}$ The CSO's must then justify

269. Id. at 730 n.16.

270. Id. at 729 (footnote omitted).

271. Craig v. Boren, 429 U.S. 190, 199 (1976).

272. Id. at 200 .

273. Id. at 201.

274. Id. at 201-02, 204 ("[T] represents a legitimate, accurate proxy for the regulation of drinking and driving.").

275. See supra text accompanying notes 216-52.

276. Most single-sex CSO's are unlikely to deny their gender-based membership policies. Nevertheless, plaintiffs also must show standing under the "case or controversy" requirement of Article III. Plaintiffs can satisfy this requirement by showing actual or threatened injury resulting from the CSO's allegedly illegal conduct. See Heckler v. Mathews, 465 U.S. 728, 738-40 (1984) (stigma of being denied equal treatment on the basis of gender confers standing); Craig v. Boren, 429 U.S. 190, 194-95 (1976) (potential economic injury confers standing).

Thus, to challenge a single-sex CSO's membership policies, a plaintiff probably can establish standing by demonstrating an affront to her human dignity, an immediate injury to her material 
their gender-based classification policies under both prongs of the intermediate scrutiny test. According to the standards articulated in Mississippi University for Women and Craig v. Boren, single-sex CSO's cannot ineet this burden.

Single-sex CSO's often contend that their inembership policies safeguard associational freedoins. In terms of the intermediate scrutiny test, this arguinent asserts that single-sex meinbership policies serve the important governmental objective of allowing CSO members to associate with others on whatever basis they desire. While the protection of associational freedoins inay constitute an important state interest in the abstract, $^{277}$ this justification is neither legitimate nor permissible as applied to CSO's. First of all, no evidence exists that public universities purposefully preserved or authorized single-sex CSO's for this reason. More likely, most public universities probably have not considered the issue and simply condone single-sex CSO's through imitation of the past.

Even if one accepts associational freedom as the state's actual objective, this objective is not permissible in the CSO setting because it is based on "fixed notions concerning the roles and abilities of males and females."278 Most public universities already require "sponsored" CSO's to select members without regard to race, rehgion, or national origin. ${ }^{279}$ Universities with such policies show their behef that race, religion, and nationality are not relevant factors in assessing an individual's qualifications for CSO meinbership. Yet, by allowing single-sex CSO's, these same universities indicate tliat they consider gender to be relevant in assessing compatibility, congeniahty, responsibility, loyalty, and other CSO qualifications. ${ }^{280}$ State action based on sucli "archaic and stereotypic notions"281 can never be an important governinental objective. ${ }^{282}$

Another atteinpt to legitimate single-sex CSO's focuses on their inembers' interest in bodily privacy. The crux of this arguinent is that

situation, or a potential injury to her economic earning power. See supra text accompanying notes 13-22.

277. For a discussion of the values embodied in associational freedoms, see Karst, supra note 169, at 629-39; Marshall, supra note 19, at 86-89; supra text accompanying notes 140-51.

278. Mississippi Univ. for Women v. Hogan, 458 U.S. 715, 725 (1982).

279. See supra text accompanying notes $245-46$.

280. The fact that universities prohibit single-race and single-religion membership policies undercuts the argument that the objective of single-sex CSO's is to protect associational freedoms. It shows that public universities are concerned more with preserving the traditional gender distinction between fraternities and sororities than with allowing CSO's complete freedom in membership selection.

281. Mississippi Univ. for Women, 458 U.S. at 725 (quoted approvingly in Heckler v. Mathews, 465 U.S. 728, 744 (1984)).

282. A state actor's asserted objective for a gender classification must satisfy both prongs of the intermediate scrutiny test. See supra notes 259-64 and accompanying text. Consequently, failure to survive the "important governmental objective" prong makes it unnecessary to determine whether single-sex membership policies are "substantially related" to associational freedom. 
the biological differences between men and women cause both sexes to desire privacy from one another in dressing, bathing, and other personal situations. ${ }^{283}$ While preserving bodily privacy may be an important state interest, ${ }^{284}$ the maintenance of single-sex CSO's is not "substantially related" to achieving that objective. The membership policies of singlesex CSO's usually do not prevent members of the excluded sex from being present at the CSO. This presence does not create serious problems because CSO members have their privacy imterests adequately safeguarded by their separate rooms. Indeed, the widespread integration of the sexes $\mathrm{m}$ coed dormitories clearly demonstrates that privacy interests can be protected by segregating mdividual bedrooms and bathrooms rather than entire facilities. Just as the Craig $v$. Boren Court found an "unduly tenuous" correlation between gender and drunken driving, ${ }^{285}$ single-sex membership is a tenuous and overbroad method for protecting bodily privacy at CSO's. Hence, such membership policies fail the second prong of the intermediate scrutimy test. ${ }^{286}$

Finally, some single-sex CSO's might argue that they serve the objective of providing college students with a sense of stability and community. ${ }^{287}$ But even assuming that this objective is important, single-sex membership policies are neither directly nor significantly related to its achievement. The social value of CSO's lies in their ability to bring together compatible people. Although members of either sex may find desirable personal qualities present more often in individuals of their own gender, these characteristics are not gender-based. ${ }^{288}$ Some college-age women are certainly more suitable, in terms of personality and congeniality, for inembership in a currently all-male CSO than are some collegeage inen. Since gender is not a "legitimate, accurate proxy"289 for compatibility, CSO's can retain their congenial atmosphere without genderbased membership practices. These practices serve not to promote stabil-

283. This privacy interest justifies such segregated facilities as separate lockerrooms and bathrooms. See Note, supra note 42, at 149.

284. See Brooks v. ACF Indus., 537 F. Supp. 1122 (S.D. W. Va. 1982) (industrial plant can refuse to employ female janitors to clean men's bathhouses); Fesel v. Masonic Home, 447 F. Supp. 1346 (D. Del. 1978) (nursing home can refuse to employ men as nurse's aides under title VII due to female residents' interest in bodily privacy), aff'd mem., 591 F.2d 1334 (3d Cir. 1979). See generally Bratt, Privacy and the Sex BFOQ: An Immodest Proposal, 48 ALB. L. REv. 923 (1984).

285. Craig v. Boren, 429 U.S. 190, 201 (1976).

286. Similarly, the membership policies of single-sex CSO's are not "substantially related" to the governmental objective of preventing premarital sexual interaction. Single-sex CSO's often allow members of the excluded sex to visit, play, and sleep at the CSO. Hence, their restrictive membership policies probably have little impact on the amount of campus sexual activity.

287. See Comment, supra note 12 , at 442 .

288. Most psychologists believe that such personality traits are acquired through a combination of nature and nurture. For a discussion of the impact of psychological theories on the legal analysis of gender classifications, see Rhode, supra note 7, at 119-20; supra note 28.

289. Boren, 429 U.S. at 204. 
ity and community, but only to preclude individual consideration of all CSO applicants. Hence, gender-based membership policies at CSO's fail the intermediate scrutiny test because, at best, they provide administrative convenience in membership selection, ${ }^{290}$ and, at worst, they perpetuate inaccurate and dangerous societal stereotypes. ${ }^{291}$

In conclusion, plaintiffs can persuasively argue that the single-sex membership pohicies of CSO's at public umversities are unconstitutional. Since public universities are an extension of the state and enjoy a syinbiotic relationship witl their CSO's, the membership policies of these CSO's constitute state action. This state action violates the equal protection clause because it classifies individuals on the basis of their gender for no purpose substantially related to an important governmental objective. Instead, this single-sex systein serves only to perpetuate the stereotype that college-age men and woinen liave innate personahity differences that niake then more coinpatible with nenibers of their own gender. This "archaic and overbroad generalization" 292 about the sexes is precisely tlie type of state action that the fourteentli amendinent should prohibit.

\section{CONCLUSION}

This Comment has examined the statutory and constitutional means available to a plaintiff who wishes to challenge the membership policies of a single-sex CSO. ${ }^{293}$ The purpose of this Comment, however, is not to inspire lawsuits against fratermities and sororities. Rather, its purpose is to prompt state officials, umversity administrators, CSO members, and others to reevaluate the institutional values associated with single-sex memberslip policies. The individual and societal harms caused and perpetuated by these policies are significant; the traditional justifications offered for thein are no longer tenable. American society has experienced a treinendous integration of the sexes in recent decades. The era of the

290. In Reed v. Reed, 404 U.S. 71 (1971), under the less stringent "rational basis" test, the Court struck down an Idaho statute that had a similar effect. The statute granted a preference to males in becoming the administrator of a decedent's estate. Idaho attempted to justify this preference by arguing that men usually had more business experience than women and by emphasizing that such an automatic preference reduced the workload of probate courts. In holding the statute unconstitutional, the Court reasoned that the administrative convenience rationale of "eliminat[ing] hearings on the merits, is . . forbidden by the Equal Protection Clause." Id. at 76.

291. See supra text accompanying notes 19-22.

292. Boren, 429 U.S. at 198 (quoting Schlesinger v. Ballard, 419 U.S. 498, 508 (1975)).

293. One means not discussed in this Comment is the possibility of revoking a single-sex CSO's tax-exempt status. See Rhode, supra note 7, at 126 n.92 (1986); Comment, Taxing Sex Discrimination: Revoking Tax Benefits of Organizations Which Discriminate On the Basis of Sex, 1976 ARIZ. ST. L.J. 641 (1976); $c f$. Bob Jones Univ. v. United States, 461 U.S. 574 (1983) (upholding revocation of racially discriminatory private school's tax-exempt status); supra note 124 (indicating that federal and state authorities generally do grant tax-exempt status to private clubs even where these clubs discriminate on the basis of gender). 
single-sex college is gone, ${ }^{294}$ the era of the single-sex club is fading, ${ }^{295}$ and the era of equality between inen and woinen inay be on the horizon. Integrating the membership policies of CSO's would be another step in the right direction.

Daniel L. Schwartz*

294. The predominance of coeducational universities is noted in B. HOWARD, THE MIXED SCHOOL: A STUDY OF COEDUCATION $41-48$ (1978). The decline of single-sex colleges is chronicled in Bales \& Sharp, Women's Colleges - Weathering $A$ Difficult Era With Success and Stamina, 13 CHANGE, Oct. 1981, at 53 (only $2.3 \%$ of college women attended all-female institutions in 1980); Ingalls, Virginia's All-Male Hampden-Sydney: Vision of the 'Mythical College of 1958', CHron. Higher EDUC., Sept. 18, 1985, at 3 (only 10 all-male colleges existed by 1985); see also text accompanying supra note 7.

295. See Board of Directors of Rotary Int'1 v. Rotary Club, 107 S. Ct. 1940 (1987) (deseribed supra in text accompanying notes 152-57); Roberts v. United States Jaycees, 468 U.S. 609 (1984) (described supra in text accompanying notes 138-51); New York State Club Ass'n v. City of New York, 69 N.Y.2d 211, 505 N.E.2d 915, 513 N.Y.S.2d 349 (described supra at note 55), prob. juris. noted, 108 S. Ct. 62 (1987) (oral arguments before Supreme Court described supra at note 152).

* A.B. 1985, Princeton University; third-year student, Boalt Hall School of Law, University of California, Berkeley. 